\title{
Antivenin plants used for treatment of snakebites in Uganda: ethnobotanical reports and pharmacological evidences
}

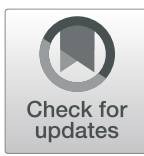

\author{
Timothy Omara ${ }^{1,2^{*}} \mathbb{D}$, Sarah Kagoya ${ }^{3,4}$, Abraham Openy ${ }^{5}$, Tom Omute ${ }^{6}$, Stephen Ssebulime ${ }^{7}$, \\ Kibet Mohamed Kiplagat ${ }^{8}$ and Ocident Bongomin ${ }^{9}$
}

\begin{abstract}
Snakebite envenomation is a serious public health concern in rural areas of Uganda. Snakebites are poorly documented in Uganda because most occur in rural settings where traditional therapists end up being the first-line defense for treatment. Ethnobotanical surveys in Uganda have reported that some plants are used to antagonize the activity of various snake venoms. This review was sought to identify antivenin plants in Uganda and some pharmacological evidence supporting their use. A literature survey done in multidisciplinary databases revealed that 77 plant species belonging to 65 genera and 42 families are used for the treatment of snakebites in Uganda. The majority of these species belong to family Fabaceae (31\%), Euphorbiaceae (14\%), Asteraceae (12\%), Amaryllidaceae $(10 \%)$ and Solanaceae (10\%). The main growth habit of the species is shrubs (41\%), trees (33\%) and herbs (18\%). Antivenin extracts are usually prepared from roots (54\%) and leaves (23\%) through decoctions, infusions, powders, and juices, and are administered orally (67\%) or applied topically (17\%). The most frequently encountered species were Allium cepa, Carica papaya, Securidaca longipedunculata, Harrisonia abyssinica, and Nicotiana tabacum. Species with global reports of tested antivenom activity included Allium cepa, Allium sativum, Basella alba, Capparis tomentosa, Carica papaya, Cassia occidentalis, Jatropa carcus, Vernonia cinereal, Bidens pilosa, Hoslundia opposita, Maytensus senegalensis, Securinega virosa, and Solanum incanum. There is need to identify and evaluate the antivenom compounds in the claimed plants.
\end{abstract}

Keywords: Antiophidic, Antivenin, Snakebite, Traditional medicine, Uganda

\section{Introduction}

Snake envenoming is a global health problem and a justification for morbimortality and various socio-economic losses. A recent conservative global estimate points that about 5.5 million snakebite cases are encountered every year causing about 2 million deaths $[1,2]$. Up to 500,000 of these cases are reported in Africa [3-5]. In 2002, 108 cases of snakebites were reported in Gulu Regional Hospital (Uganda) though none of the victims died [6].

\footnotetext{
*Correspondence: timothy.omara@agroways.ug; prof.timo2018@gmail.com; prof.timo2018@mu.ac.ke

'Department of Chemistry and Biochemistry, School of Biological and Physical Sciences, Moi University, Uasin Gishu County, Kesses, P.O.Box 3900-30100, Eldoret, Kenya

${ }^{2}$ Department of Quality Control and Quality Assurance, Product

Development Directory, AgroWays Uganda Limited, Plot 34-60, Kyabazinga Way, P.O. Box 1924, Jinja, Uganda

Full list of author information is available at the end of the article
}

About 151 cases were reported in neighboring Kenya in 1994 with $19 \%$ of these from venomous snakes [7].

A recent study [8] in 118 health facilities throughout Uganda revealed that only $4 \%$ of the facilities stocked antivenin sera, thus most victims rarely seek medical care when bitten by snakes. A retrospective part of this study showed that in 140 surveyed facilities, 593 snakebite cases were recorded within six months with bites reported in the rainy seasons from April 2018 to June 2018 and then October 2018 to December 2018 [8]. Thus, fatalities in rural areas are due to lack of antidotes within the $24 \mathrm{~h}$ recommended $[6,9,10]$ and antisera administration problems [11, 12].

Snakes are taxonomically carnivorous vertebrates of class Reptilia, order Squamata, sub-order Serpentes and families: Colubridae, Boidae, Elapidae, Pythonidae, Viperidae that characteristically kill their prey by constriction 
rather than envenomation $[13,14]$. Most bites are due to circumstantial stepping on the snakes by unprotected or barefooted victims $[6,15]$, snake ecology [16] while others are initiated by malevolent and alcohol-intoxicated victims [17-19]. Over 3500 species of snakes have been classified and about $600(15-17 \%)$ of these are venomous $[1,20]$. East Africa is home to about 200 species of snakes and 145 of these from 45 genera and 7 families are found in Uganda [21]. Many are harmless or are a rarity though the puff adder (Bitis arietans), Gabon viper (Bitis gabonica), green or Jameson's mamba (Dendroaspis jamesoni), black mamba (Dendroaspis polylepis), forest cobra (Naja melanoleuca), and black-necked spitting cobra (Naja naja nigricollis) are listed as venomous [10, 22].

Snake venom is secreted by snake oral glands and is injected subcutaneously or intravenously through the fangs into the victim on the hands, feet, arms, or legs [23]. Venoms are water-soluble, acidic, and have a specific gravity of about 1.03 [24]. The quantity, lethality, and composition of venoms vary with the age and species of the snake, time of the year, geographic location as well as the envenoming snake's diet. A snake venom is a complex mixture of toxic proteins such as cardiotoxins, neurotoxins, metalloproteinases, nucleotidases, phospholipases $A_{2}$, serine proteinases, acetylcholinesterase nitrate, hyaluronidases, phosphomonoesterase and phosphodiesterase [25] which are injected to immobilize the victim $[10,26]$. The toxins cause haemotoxicitydamage to blood vessels resulting in spontaneous systemic and muscle paralysis, myolysis, arrhythmias, cardiac, and renal failure [6].

At present, serum antivenom immunotherapy is the mainstay of treatment reported for snake envenomation $[6,10,17,26]$. Antisera are either derived from horse serum after injecting it with sublethal doses of the venom (Antivenin Polyvalent) or sheep serum (Crotalidae Polyvalent Immune Fab) [19]. Though antivenom serum is lifesaving, it is associated with the development of immediate or delayed hypersensitivity (anaphylaxis or serum sickness) and does not prevent local tissue damage. The side effects are thought to be due to the action of non-immunoglobulin proteins present in high concentrations in antisera [27]. Worse still, there is a paucity of snake venom antiserum in rural Africa that even in the presence of money, it may not be readily available for purchase $[6,17]$. This is in part attributed to the decline in antivenom production in Africa due to denationalization of the manufacturing industries by African countries [28], lack of ready market and low profits from the business. Thus, several attempts have been made to develop snake venom antagonists from other sources including plants, dogs, rabbits, camelids, and avian eggs [12, 27, 29-33].
The use of plants in addressing medical challenges have been witnessed since antiquity and is regaining shape in the modern era due to their safety, effectiveness, cultural preferences, inexpensiveness, abundance, and availability. In Uganda, more than 230 species of angiosperms belonging to about 168 genera and 69 families are being utilized for treatment of erectile dysfunction, malnutrition, sickle cell anemia, hernia, venereal diseases (syphilis, HIV, and gonorrhoea), post-partum hemorrhage, snakebites, cancer, menorrhagia, threatened abortion, skin diseases, jaundice, and cough [34-60]. This study compiled information on antivenin plants reported in different districts of Uganda and presented some experimental evidence supporting their use in antivenom therapy.

\section{Methodology}

\section{Description of the study area}

Uganda is a landlocked country straddling the equator in Eastern Africa [61]. It is flanked by Lake Victoria, Tanzania, and Rwanda to the south, Kenya to the East, South Sudan to the North and Democratic Republic of Congo to the West (Fig. 1). The climate experienced is equatorial moderated by relatively high altitudes with a mean annual temperature of $20.5{ }^{\circ} \mathrm{C}$. The country's population is estimated to be 35.92 million with 5 main ethnic families: Nilotics (Acholi, Alur, Padhola, Lulya, and Jonam), Bantu (Baganda, Banyankole, Batoro, Bagwere, Bakiga, Bakiga, Banyarwanda, Bakonjo, Banyoro, and Bakiga), Hamities (mainly constituted by the Bahima), the Nilo-Hamities (Teso, Karamojong, Kakwa, Sebei, Labwor, and Tepeth) and the Sudanics (Lugwara, Madi, and Lendu) [62]. Health care services are inadequate [63], and access to allopathic drugs is limited in rural areas due to their prohibitive cost, poor transport network, chronic poverty and the general belief in efficacy of traditional medicine than western medicine [64].

\section{Literature search strategy}

Relevant original articles, books, thesis, dissertations, patents, and other reports written in English and other local languages on ethnobotany and pharmacological evidences on snakebites in Uganda were searched in Scopus [65], Web of Science [66], PubMed [67], Science Direct [68], Google Scholar [69], and Scientific Electronic Library Online (SciELO) [70] from July 2019 to September 2019. The key search words used were "snakebite," "vegetal," "traditional medicine," "ethnobotany," "alternative medicine," "ethnopharmacology," "antivenom," "antiophidian," "antitoxin," "snake antidotes," and "Uganda." The botanical names of the plants were vetted in botanical databases: the Plant List [71], International Plant Names Index (IPNI) [72], NCBI taxonomy browser [73], and Tropicos [74]. Where a given 


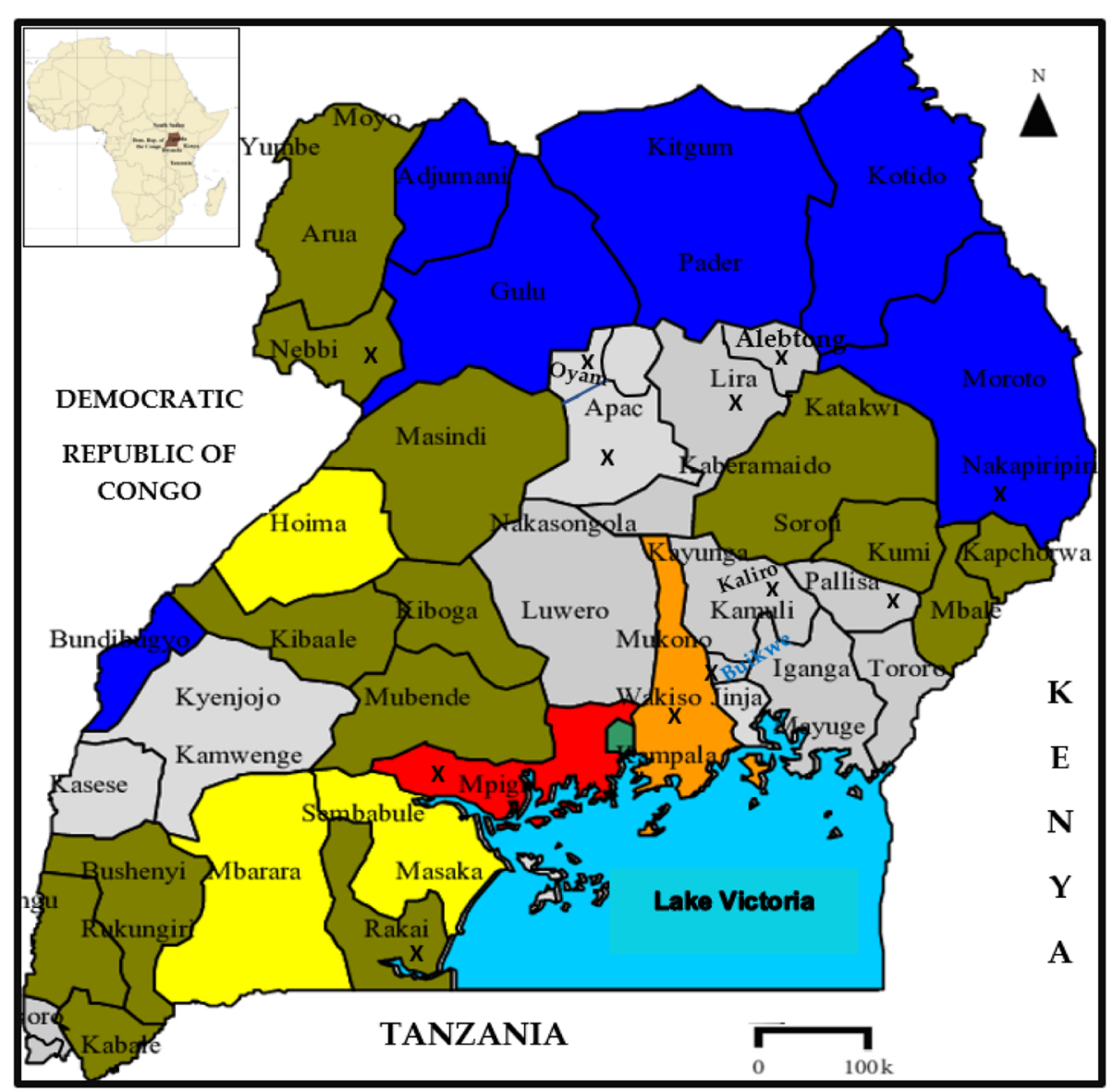

Fig. 1 Map of Uganda showing the location of the districts with reports of ethnobotanical surveys (marked X). Inset is the location of Uganda on the African continent

species was considered as distinct species in different reports, the nomenclature as per the botanical databases took precedence. The families, local names (Lango, Acholi, Ateso, Luganda, Lunyoro, Rukiga, and Lusoga), growth habit, part(s) used, conservation status, preparation and administration mode, status of antivenin activity investigation of the plants, and the districts where the plants were surveyed are reported (Table 1, Additional file 1). Pertaining to pharmacological reports, the snake venom studied, phytochemicals, and positive results obtained using plants identified by this study (or species from the same genus) are reported. In some cases, some activities of the plant extracts such as antioxidant and radical scavenging activities are reported as these are some of mechanisms by which snake venoms are countered.

\section{Results and discussion}

Only full-text articles in English, Lango, Acholi, Ateso, Luganda, Lunyoro, Rukiga, and Lusoga were considered. A total of 15 articles (13 in English, 1 in Luganda, and 1 in Lusoga) with information on antivenin plants were retrieved, but two of these did not meet inclusion criteria because one was not a full-text article while the other had only one botanically unidentified antivenin plant. Thus, the following reports of interest specifically on the subject of antivenin plants in Uganda were retrieved (Table 1).

\section{Traditional concept of snakebites in Uganda}

From the electronic survey of data, it is indubitable that the local communities in Uganda have different perceptions about snakebites. The beliefs appear to be clanrelated and include snakes "can protect" (among the Baganda) $[18,75]$ or "are dangerous and connected to witchcraft" in most communities [8]. By comparison, the Luo of Kenya associate snakes with witchcraft [76].

From the survey, 77 plant species from 65 genera belonging to 42 botanical families claimed as antiophidic in Uganda were retrieved (Table 1, Additional file 1). The most cited families were Fabaceae (31\%), Euphorbiaceae (14\%), Asteraceae (12\%), Amaryllidaceae (10\%), and Solanaceae (10\%) (Fig. 2). Most families encountered in this study have reported antivenin potential in treating or avoiding snakebites in other countries across the globe. For example, Apocynaceae, Aristolochiaceae, 
Table 1 Antivenin plants used in rural communities of Uganda

\begin{tabular}{|c|c|c|}
\hline Plant family & Latin botanical name & References \\
\hline Acanthaceae & Asystasia schimperi T. Anders. & [42] \\
\hline Amaryllidaceae & Allium cepa L. & {$[41,42,49]$} \\
\hline Amaryllidaceae & Allium sativum $\mathrm{L}$. & [49] \\
\hline Amaryllidaceae & Crinum kirkii & [41] \\
\hline Amaryllidaceae & Scadoxus multiflorus (Martyn) Raf. & {$[10,42]$} \\
\hline Apocynaceae & Carrisa edulis & {$[50]$} \\
\hline Apocynaceae & Thevetia peruviana (Pers.) Schumann & {$[42]$} \\
\hline Aristolochiaceae & Aristolochia tomentosa Sims. & {$[50]$} \\
\hline Aristolochiaceae & Aristolochia elegans Mast. & {$[42]$} \\
\hline Asclepiadaceae & Cryptolepis sanguinolenta (Lindl.) Schltr & {$[42]$} \\
\hline Asparagaceae & Sansevieria dawei Stapf & {$[38]$} \\
\hline Asparagaceae & Sansevieria trifasciata var. trifasciata & [10] \\
\hline Asteraceae & Bidens pilosa L. & {$[42]$} \\
\hline Asteraceae & Crassocephalum mannii (Hook.f.) Milne-Redh. & {$[35]$} \\
\hline Asteraceae & Echinops amplexicaulis Oliv. & {$[46]$} \\
\hline Asteraceae & Microglossa pyrifolia (Lam.) O. Kuntze & [42] \\
\hline Asteraceae & Vernonia cinerea $(\mathrm{L})$ Less & {$[41,42]$} \\
\hline Basellaceae & Basella alba $\mathrm{L}$. & [39] \\
\hline Boraginacea & Trichodesma zeylanicum (L.) R.Br. & [41] \\
\hline Cleomaceae & Cleome gynandra L. & [35] \\
\hline Capparidaceae & Capparis tomentosa Lam. & {$[42]$} \\
\hline Caricaceae & Carica papaya L. & {$[41,42,50]$} \\
\hline Celastraceae & Maytensus senegalensis (Lam) Exell. & [41] \\
\hline Combretaceae & Combretum collinum Fresen & [41] \\
\hline Combretaceae & Combretum molle ex G.don. & [41] \\
\hline Commelinaceae & Murdannia simplex Vahl. Branan & {$[35]$} \\
\hline Compositae & Aspilia africana C.D Adams & {$[46]$} \\
\hline Convolvulaceae & Hewittia sublobata L. Kuntze & [49] \\
\hline Convolvulaceae & Ipomoea batatas (L.) Lam. & [42] \\
\hline Dracaenaceae & Dracaena steudneri Engl. & [49] \\
\hline Ebenaceae & Euclea divinorum Hiern & [42] \\
\hline Euphorbiaceae & Acalypha bipartita Muell. Arg. & {$[42,47]$} \\
\hline Euphorbiaceae & Croton macrostachyus Hochst. ex. Delile & [49] \\
\hline Euphorbiaceae & Euphorbia tirucalli L. & [35] \\
\hline Euphorbiaceae & Jatropha curcas L. & {$[42]$} \\
\hline Euphorbiaceae & Ricinus communis L. & {$[35,42]$} \\
\hline Euphorbiaceae & Securinega virosa (Willd) Baill. & [41] \\
\hline Fabaceae & Acacia seyal Del. var. fistula (Schweinf.) Oliv. & {$[42]$} \\
\hline Fabaceae & Acacia species & {$[42]$} \\
\hline Fabaceae & Albizia coriaria (Welw. ex) Oliver & [42] \\
\hline Fabaceae & Canavalia ensiformis L. D.C & [10] \\
\hline Fabaceae & Indigofera arrecta Host. A. Rich. & {$[42,49]$} \\
\hline Fabaceae & Indigofera garckeana Vatk & {$[42]$} \\
\hline Fabaceae & Indigofera capitata Forsk. & [41] \\
\hline
\end{tabular}


Table 1 Antivenin plants used in rural communities of Uganda (Continued)

\begin{tabular}{|c|c|c|}
\hline Plant family & Latin botanical name & References \\
\hline Fabaceae & Pseudarthria hookeri Wight and Arn. & {$[42,48]$} \\
\hline Fabaceae & Senna occidentalis (L.) Link & [42] \\
\hline Fabaceae & Senna septemtrionalis (Viv.) I. et B. & [39] \\
\hline Fabaceae & Senna siamea (Lam.) Irwin and Barneby & [42] \\
\hline Fabaceae & Senna singueana (Del.) Lock & [42] \\
\hline Lamiaceae & Hoslundia opposita Vahl & [42] \\
\hline Lamiaceae & Plectranthus barbatus & {$[37,50]$} \\
\hline Leguminosae & Cassia occidentalis L. & [35] \\
\hline Liliaceae & Anthericum cameroneii Bak & [41] \\
\hline Loganiaceae & Strychnos innocua Del. & [41] \\
\hline Malvaceae & Urena lobata L. & [42] \\
\hline Melastomataceae & Tristemma mauritianum J.F. Gmel. & [41] \\
\hline Meliaceae & Ekebergia capensis Sparrm & [44] \\
\hline Meliaceae & Trichilia ematica Vahl & {$[38,46]$} \\
\hline Menispermaceae & Cissampelos muchronata A.Rich. & {$[41,49]$} \\
\hline Moraceae & Ficus natalensis Hochst. & [42] \\
\hline Myricaceae & Morella kandtiana (Engl.) Verdic and Polhill & [49] \\
\hline Papillionaceae & Ormocarpum trachycarpum & {$[50]$} \\
\hline Passifloraceae & Adenia cissampeloides (Hook.) Harms & [42] \\
\hline Poaceae & Imperata cylindrica (L.) P. Beauv & {$[42,49]$} \\
\hline Poaceae & Sporobolus pyramidalis P. Beauv. & [42] \\
\hline Polygalaceae & Securidaca longipedunculata Fres. & {$[41,42,50]$} \\
\hline Rosaceae & Rubus rigidus Sm & [49] \\
\hline Rubiaceae & Gardenia ternifolia Schumach. and Thonn. & [42] \\
\hline Rutaceae & Citrus sinensis (L.) Osb. & [42] \\
\hline Rutaceae & Fagaropsis angolensis (Engl.) Dale & [59] \\
\hline Simaroubaceae & Harrisonia abyssinica Oliv. & {$[41,42,50]$} \\
\hline Solanaceae & Datura stramonium L. & [41] \\
\hline Solanaceae & Nicotiana tabacum L. & {$[42,49,59]$} \\
\hline Solanaceae & Solanum aculeatissimum Jacq & {$[41,46]$} \\
\hline Solanaceae & Solanum incanum L. & {$[41,42]$} \\
\hline Umbifellifereae & Steganotaenia araelicea Hoscht & [41] \\
\hline Verbenaceae & Lantana camara L. & [50] \\
\hline
\end{tabular}

Asteraceae, Convolvulaceae, Fabaceae, and Myricaceae were cited in Kenya [17] and Tanzania [77], Meliaceae in Ghana [78], Fabaceae in Rwanda [79], Asparagaceae, Leguminosae, and Menispermaceae in Sudan [80], Acanthaceae, Apocynaceae, Asteraceae, Capparaceae, Cariaceae, Combretaceae, Convulaceae, Ebenaceae, Eurphorbiaceae, Fabaceae, Malvaceae, Meliaceae, and Poaceae in Ethiopia [81] and Pakistan [82], Fabaceae, Aristolochiaceae, and Lamiaceae in Djibouti [83] and Nigeria [84], Melastomataceae and Menispermaceae in Cameroon [85]. Acanthaceae, Apocynaceae, Asteraceae, Euphorbiaceae, Fabaceae, Moraceae, Rubiaceae, and Rutaceae were cited in India [86, 87],
Bangladesh [88, 89], and Central America [90]. Fabaceae is always dominant in ethnobotanical reports because of the abundance of plant species from this family [88, 91-93].

The families reported were from different districts of Uganda (Fig. 3) representing different ethnic groups with diverse cultural beliefs and practices. About $40 \%$ of the plant species were reported in Kaliro (inhabited by the Basoga) followed by $21 \%$ from Lira (occupied by the Lango) and 11\% from Mukono-Buikwe frontier occupied by the Baganda. In a similar cross-cultural comparison of antiophidic floras in the Republic of Kenya, Owuor and Kisangu [17] reported that two culturally and 


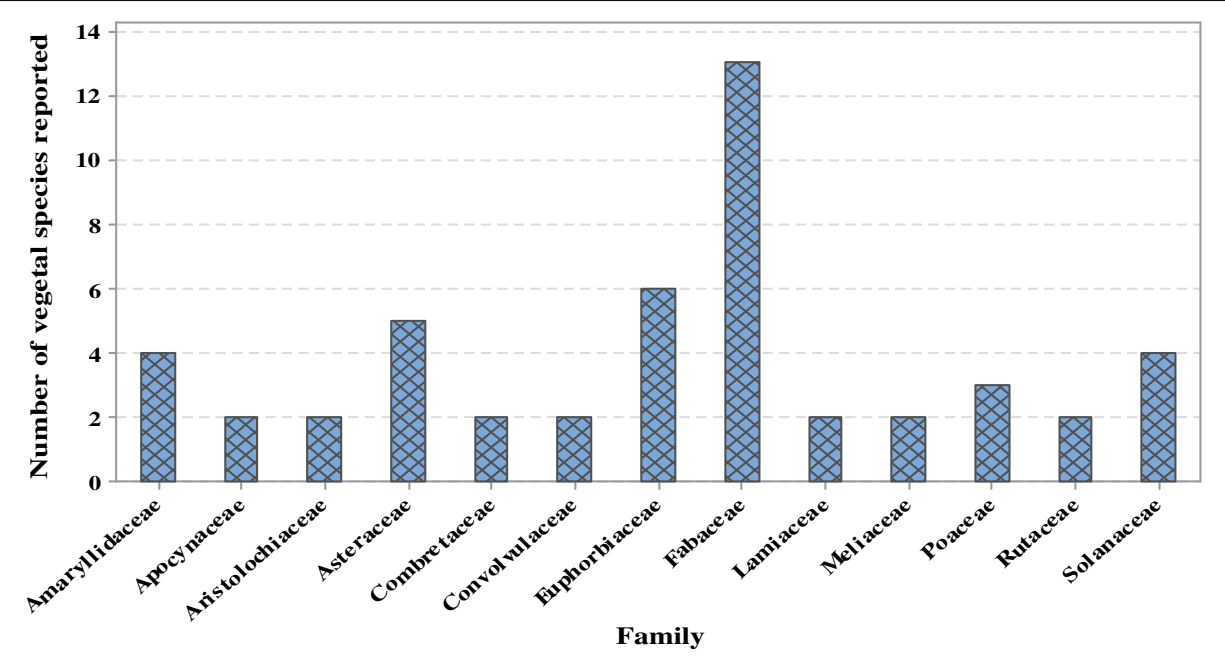

Fig. 2 Major families from which vegetal antivenins are obtained in Uganda

floristically distinct African groups (Kamba and Luo) had similar knowledge of snakebites but the antivenin plants utilized by the two ethnic groups were independently derived. The abundance of antivenin plants from Kaliro, Lira, and Mukono/Buikwe could be due to the presence of forest reserves in these districts. Kaliro, Namalemba, and Namukooge local forest reserves are found in Kaliro [94]. The district is also rich in water resources such as Lake Nakuwa, River Mpologoma, Naigombwa, and Lumbuye wetlands which provide rainfall for the growth of plants. Lira District has Lake Kwania, Okole, Moroto and Olweny wetland systems which support the growth of plants [95]. The district gazetted over
1000 hectares of land for forest conservation and this serves as a good source of plants for traditional medicine [96]. The Mukono-Buikwe frontier has Mabira forest reserve which has been protected since 1932 and contains a number of endangered plant species in Uganda [97]. The rainforest is a rain catchment for areas supplying River Nile and Ssezibwa River and has rainfall throughout the year thus plants flourish in this area [98].

Growth habit, parts used, preparation, and administration of antivenin preparations

Antivenin plants used in Uganda are majorly shrubs (41\%), trees (33\%) and herbs (18\%) and the commonly

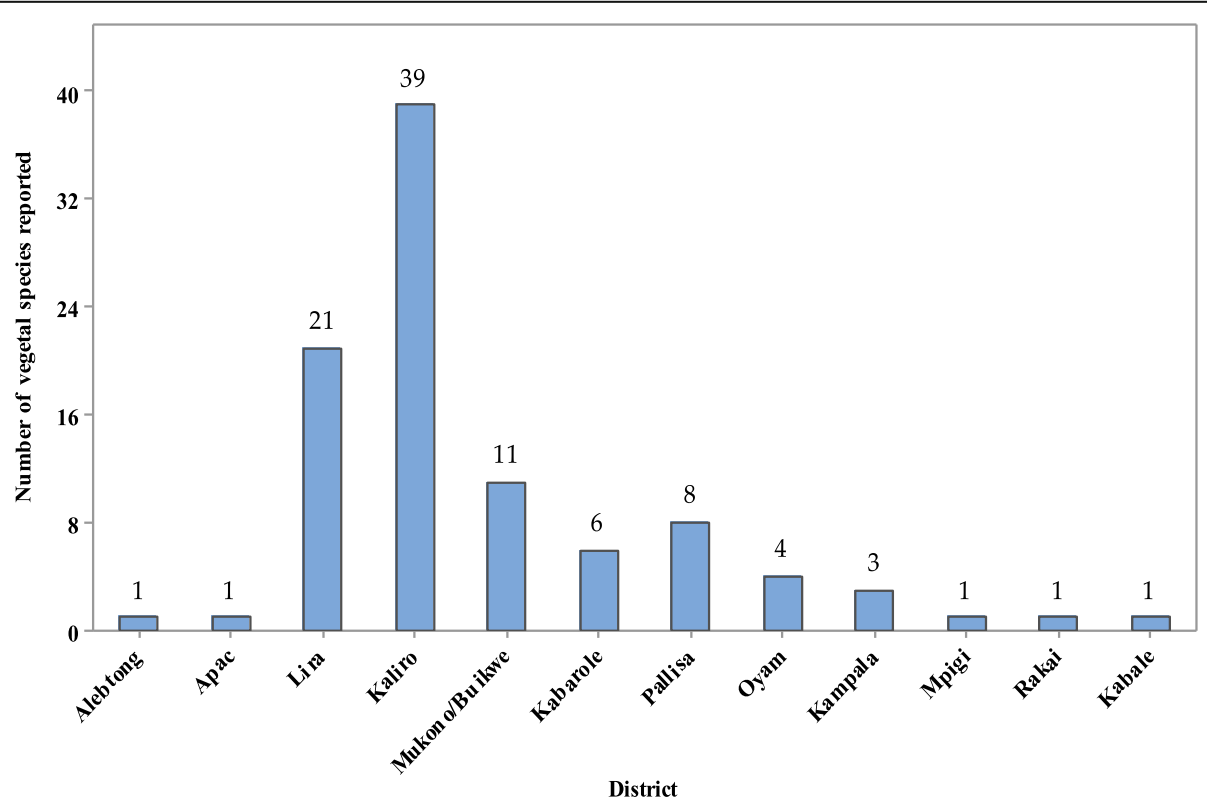

Fig. 3 Distribution of antivenin plant species in Ugandan districts as per ethnobotanical reports 
used plant parts are roots (54\%) and leaves (23\%) followed by whole plant (4\%), bark (4\%), and tuber (4\%) (Figs. 4 and 5). The regular use of roots and leaves in antivenin preparations is a characteristic feature of traditional antivenin therapy $[17,81,86,99,100]$, no wonder some of these plants are named "snakeroot" in some rural communities [101]. Comparatively, embryonal plant parts such as fruits, seeds, buds, bulbs, and flowers which have reputation for accumulating certain compounds are less frequently used, concordant with reports from other countries $[17,81]$. Majority of the plants reported grow in the wild (82\%), $14 \%$ are cultivated while $4 \%$ are semi-wild (occurs in the wild but can also be cultivated). The commonest mode of preparation is as decoctions and infusion. The plants are collected from fallow land, cultivated fields or home gardens when needed. Traditional medicine practitioners either collect herbal plants personally or hire collectors. All traditional medical practitioners cultivate some medicinal plants especially fast growing ones around their homes and shrines in order to have them within easy access when needed. The antidotes are administered orally (67\%) or applied at the point of snakebite (17\%).

In this survey, it was noted that few plant species are used against snakebites simultaneously in different districts. This could probably be attributed to the abundant distribution of the analog active substances among species especially those of family Fabaceae. Some of the plants listed are also used for wading off or discouraging snakes from reaching human and livestock abodes. In most instances, the plants possess a strong smell that causes discomfort and disorientation to snakes when they slither over them. In exceptional cases as with tobacco, the plant (dried whole plant or leaves) are burnt to produce unpleasant odor that discourages snakes (Table 2). The Lango of Northern Uganda burn bicycle, motorcycle, and vehicle tyres to discourage snakes.

\section{Other ethnomedicinal uses and toxicity of the reported antivenin plants}

Almost all the plants recapitulated in this review are employed for the treatment of various ailments. For example, Bidens pilosa L. has been reported to be useful in the treatment of more than 40 disorders including inflammation, immunological disorders, digestive disorders, infectious diseases, cancer, metabolic syndrome, and wounds among others [103-106]. Albizia coriaria (Welw. ex) Oliver is used in the management of syphilis, postpartum haemorrhage, sore throats, menorrhagia, threatened abortion, skin diseases, jaundice, cough, sore eyes, and as a general tonic [35]. Such plants tend to be used in different communities for treating snakebites and can be a justification of their pharmacological efficacy [107].

On the other hand, some of the antivenin plants cited exhibit marked toxicity. A striking example is Jatropha carcus $\mathrm{L}$. leaf and latex which contain a purgative oil (irritant curcanoleic acid and croton oil), curcin (toxalbumin), and diterpene of tigliane skeleton classified as phorbol esters [108]. Curcin has protein translation inhibitory ( $N$-glycosidase) activity whereas phorbol esters are amphiphillic molecules that can bind phospholipid membrane receptors [109]. This observation explains why some antivenin preparations in Uganda are applied topically or ingested in small amounts. Fortuitously, topical application is a better approach for reducing the local action of venoms at the bitten site.

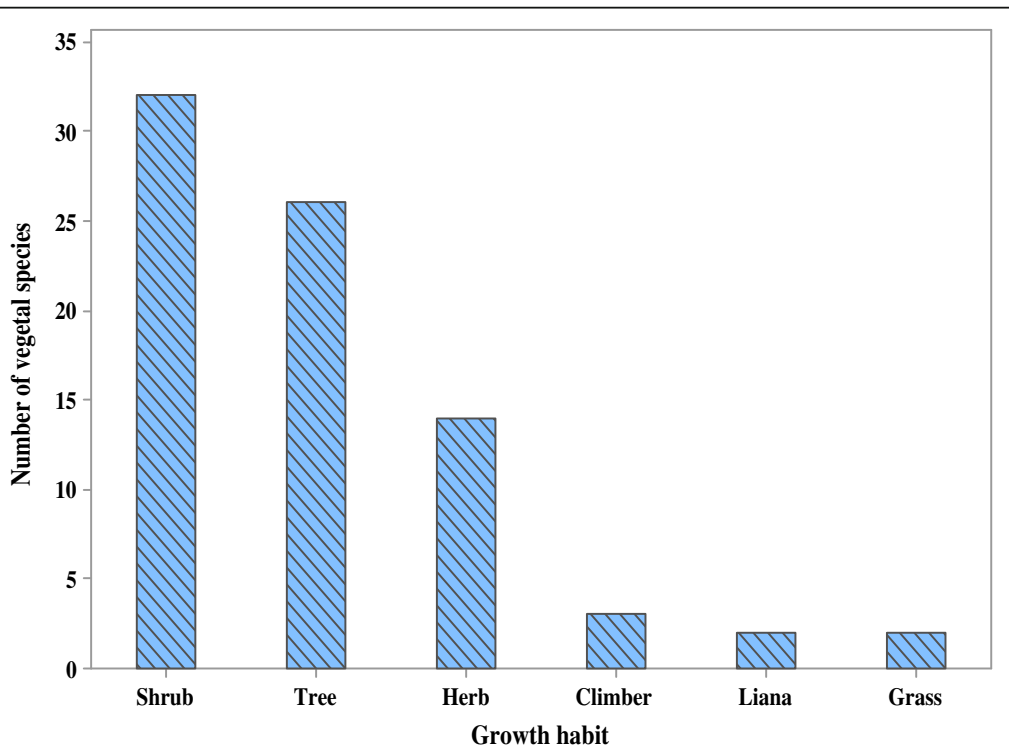

Fig. 4 Growth habit of the antivenin plants used in rural communities of Uganda 


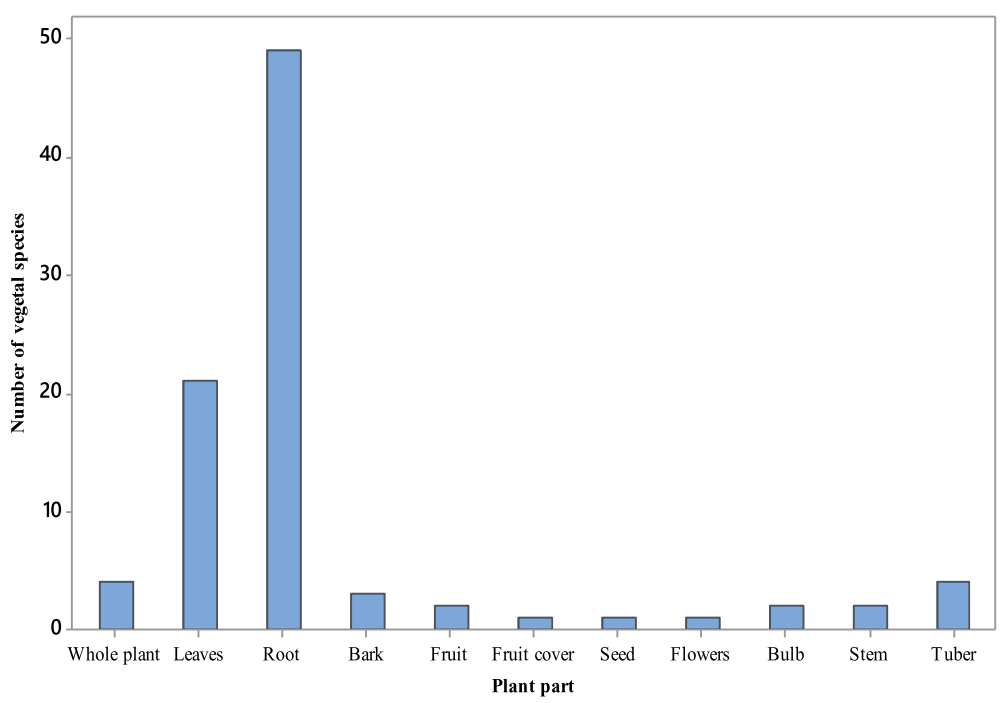

Fig. 5 Parts of antivenin plants used in rural communities of Uganda

\section{Knowledge dynamics of antivenin plants in Uganda}

Knowledge of traditional medicine and medicinal plants are usually acquired and passed on orally from the elders to the young [34]. This is comparable to reports from other African countries [17, 78]. Knowledge is gained through trainings, divine call, and in some instances, the plant to be used can be asked for from the dead [42, 59]. Because of civilization, efforts to pass on traditional medical knowledge to children is impeded by lack of interest and the fact that most children spend their youthful years in school [17, 34, 60]. Most Ugandans know that their current social conditions such as poverty, sleeping in mud houses and activities such as cultivation, hunting, and herding cattle increase their chances of getting bitten by a snake. Snakebites are always taken as exigencies with economic implications due to the expenses involved in transporting the victims for treatment, the care needed, enforced borrowing, amputation of necrosed legs, and arms as well as loss of time [8].

\section{Treatment of snakebites}

Treatment of snakebites in Uganda involves various procedures that vary from culture to culture and religion to religion, for example, Pentecostal Assemblies of God (PAG) believe prayers can treat snakebites. Use of tourniquets to tie the injured part above the affected area to prevent the venom from spreading to heart, the lungs, kidney, and other delicate parts of the body has been prescribed as a supportive first aid in Northern Uganda [6]. This is usually done at five-minute intervals to avoid the weakening of the local tissues.

Among the Baganda (Central Uganda), the use of black stones (carbonized absorptive animal bone) and Haemanthus multiflorus bulb have been reported (Fig. 6) [10]. A black stone is placed on incisions made around

Table 2 Plants used in Ugandan rural communities for repelling of snakes

\begin{tabular}{|c|c|c|c|c|c|}
\hline Family & $\begin{array}{l}\text { Botanical } \\
\text { name }\end{array}$ & $\begin{array}{l}\text { Growth } \\
\text { habit }\end{array}$ & Part used & Mode of use to prevent snakes & References \\
\hline Amaryllidaceae & Allium cepa $\mathrm{L}$ & Herb & Bulb & $\begin{array}{l}\text { Decoction made and sprinkled around the house. Snakes are discouraged by } \\
\text { the sharp onion smell. }\end{array}$ & {$[10]$} \\
\hline Amaryllidaceae & $\begin{array}{l}\text { Allium } \\
\text { sativum L. }\end{array}$ & Herb & Bulb & $\begin{array}{l}\text { Decoction made and sprinkled around the house. Snakes do not are } \\
\text { discouraged by the sharp onion smell. }\end{array}$ & [10] \\
\hline Asteraceae & $\begin{array}{l}\text { Tagetes } \\
\text { minuta }\end{array}$ & Herb & Leaves & $\begin{array}{l}\text { Plants have bitter tastes and strong smells that cause discomfort and } \\
\text { disorientation to snakes when they slither over them. }\end{array}$ & [10] \\
\hline Euphorbiaceae & $\begin{array}{l}\text { Ricinus } \\
\text { communis }\end{array}$ & Herb & $\begin{array}{l}\text { Leaves/ } \\
\text { whole plant }\end{array}$ & $\begin{array}{l}\text { Plant have strong smell that cause discomfort and disorientation to snakes } \\
\text { when they slither over them. }\end{array}$ & [10] \\
\hline Poaceae & $\begin{array}{l}\text { Cymbopogon } \\
\text { citrus }\end{array}$ & Grass & Leaves & $\begin{array}{l}\text { Decoction made and sprinkled around the house. Snakes do not like the citrus } \\
\text { smell from the leaves }\end{array}$ & [10] \\
\hline Solanaceae & $\begin{array}{l}\text { Nicotiana } \\
\text { tabacum L. }\end{array}$ & Shrub & Leaves & Planted around the house, leaves burnt & {$[10,102]$} \\
\hline
\end{tabular}




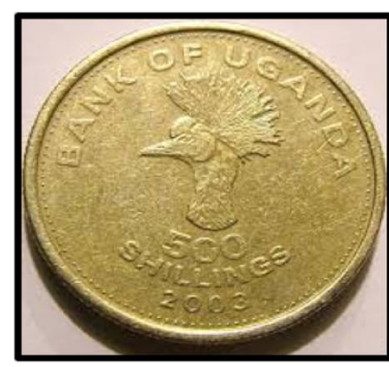

(a)

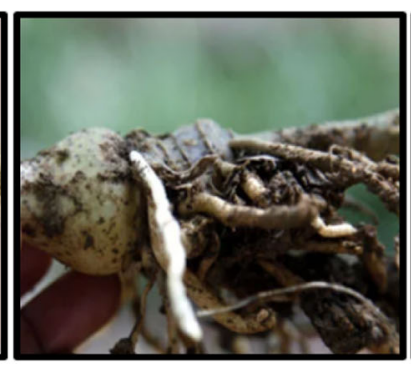

(b)

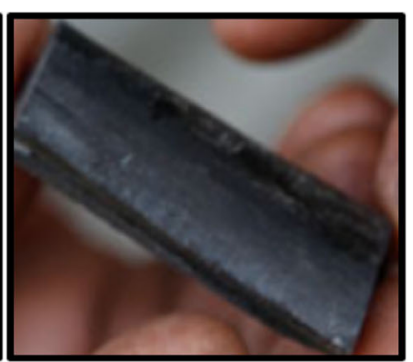

(c)

Fig. 6. Treatment of snake bites in Uganda. a 500 Uganda shillings copper coin. Side displayed is usually placed on the bite. b Haemanthus multiflorus bulb. c black stone

the bitten area until it sticks. It is administered to reassured victims and left for 20-30 minutes for it to "suck out" the poison. The stone is reported to be $30 \%$ effective and can be reused if boiled in hot water after use and can be used alongside other medical treatments [10]. For Haemanthus multiflorus, the bulb is chewed by the victim or it is crushed and put on the bite.

In Northern Uganda, the use of 500 Uganda shilling copper coins and black stones have been reported [6]. The copper coins are placed on the bite until it gets stuck and it is left to fall off on its own. In some communities like Lango of Northern Uganda, antivenin therapy involves oral administration of egg yolk and albumin similar to the therapy reported among the Luo of Kenya [17]. Overall, traditional antivenin therapy in Uganda involves administration of plant preparations to the victims [35].

Antivenin activity of plants and pharmacological evidence Pharmacological studies have revealed that some plants used in traditional medicine are able to antagonize the activity of various crude venoms and purified toxins [110-112]. Antigen-antibody interaction is the proposed mechanism through which the activity of venoms is countered by antivenins. Reported mechanisms of venom inactivation include precipitation or inactivation of the toxic venom proteins [113], inactivation, or enzyme inhibition [114], chelation [115], adjuvant action [116], antioxidant activity or a synergistic interaction of these mechanisms. Enzyme inhibition and protein precipitation are by far the most conventionally accepted mechanisms [117]. To start with, plant metabolites such as flavonoids, polyphenols, saponins, tannins, terpenoids, xanthenes, quinonoids, steroids, and alkaloids have been reported to snuggly bind to toxic proteins of snake venoms, thereby offsetting their deleterious effects. Another explained scientific possibility is the competitive blocking of the target receptors [118]. For example, atropine (an alkaloid reported in family Solanaceae) is reported to inhibit the activity of green and dark mamba
(Drendroaspis angusticeps and D. polylepsis) venoms by blocking cholinergic nerve terminals usually attacked by the venoms. Aristolochic acid I (8-methoxy-6-nitro-phenanthro(3,4-d)1,3-dioxole 5-carboxylic acid), an alkaloid present in Aristolochia species acts in the same way.

Another mechanism of snake venom inactivation involves inhibition of the active enzymes such as phospholipase $\mathrm{A}_{2}$, metalloproteases, and hyaluronidases by polyphenolic compounds such as tannins. In this scenario, the metabolites interact with the venom enzymes by non-specific binding proteins [119] through hydrogen bonding with hydroxyl groups in the protein molecules generating chemically stable complexes [120]. For example, in a study experimented with aristolochic acid I and $\mathrm{PLA}_{2}$ isolated from Viper russelli venom, molecular interactions between the two were reported to be between their hydroxyl groups which formed two hydrogen bonds with Granulocyte Marker Monoclonal Antibody (His48) and myotoxins I (Asp49) of the venom [121]. Aristolochic acid I is also an inhibitor of hyaluronidase of Naja naja venom [122]. Other examples of these are outlined in Table 3. Chelation on the other hand is reported to be effective for antivenin plant extracts with molecules (compounds) capable of binding to divalent metal ions necessary for some enzymatic activities. For the cause that chemical coordination of metal ions is indispensable for normal hydrolytic activities of phospholipases and metalloproteases, secondary metabolites capable of disrupting the enzyme-metal ion bondage inhibits enzymatic progression [166]. In antioxidation mechanism, plant metabolites (flavonoids, terpenoids, tannins, polyphenols, vitamins $\mathrm{A}, \mathrm{C}, \mathrm{E}$, and minerals such as selenium) prevent, stop or reduce oxidative damage due to phospholipase $\mathrm{A}_{2}$ activity by selectively binding to the active sites or modifying the conserved residues that are inevitable for phospholipase $\mathrm{A}_{2}$ catalytic action [119].

The efficacy of plant extracts in antivenom action tends to be related to the solvent used for the extraction of the bioactive compounds. A study [152] reported that 
Table 3 Antivenin activities of some plants used for snakebite treatment in Uganda as per global reports

\begin{tabular}{|c|c|c|c|c|c|}
\hline Plant & Part used & $\begin{array}{l}\text { Solvent } \\
\text { used }\end{array}$ & Antivenin activity (comments) & Active chemical constituents & Authors \\
\hline Allium cepa $\mathrm{L}$. & Bulb & Methanol & $\begin{array}{l}\text { Cardioprotective activity ( } 14.8 \pm 1.65 \text { units/l; } p> \\
0.5) \text { on creatine kinase isoenzyme levels to } \\
\text { neutralize snake venoms. Concentrations ( }<160 \\
\mu \mathrm{g} / \mathrm{ml} \text { ) stabilized human red blood corpuscles } \\
\text { membrane (antihemolytic) against } N \text {. naja } \\
\text { karachiensis venom, though elevated } \\
\text { concentrations were cytotoxic. Provided } 50 \% \\
\text { protection from N. naja karachiensis } \\
\text { phospholipase A (PLA }) \text { in terms of an increase in } \\
\text { pH of an egg yolk suspension. Neutralized the } \\
\text { anticoagulant effect induced by weak PLA } \\
\text { enzymes in } N \text {. naja karachiensis venom ( } 76 \% \\
\text { inhibition, coagulation time of } 106 \pm 0.57 \mathrm{~s} \text { ). } \\
\text { Quercetin is a potent inhibitor of lipoxygenase }\end{array}$ & $\begin{array}{l}\text { Quercitin, sulfurous volatile oils, oleanolic acid, } \\
\text { protocatechuric acid }\end{array}$ & $\begin{array}{l}{[123-} \\
127]\end{array}$ \\
\hline $\begin{array}{l}\text { Allium } \\
\text { sativum L. }\end{array}$ & Bulb & Methanol & $\begin{array}{l}\text { Hepatoprotective activity }(p>0.5,49 \pm 5.01 \text { and } \\
82.5 \pm 18.55 \text { units/l of aspartate aminotransferase } \\
\text { and alanine aminotransferase against } 52.5 \pm 3.51 \\
\text { and } 69.5 \pm 18.55 \text { units/l for standard antiserum) } \\
\text { assessed in rabbits. Provided } 50 \% \text { protection from } \\
\mathrm{N} \text {. naja karachiensis } \mathrm{PLA}_{2} \text { in terms of an increase } \\
\text { in pH of an egg yolk suspension. Provided } 50 \% \\
\text { protection from } \mathrm{N} \text {. naja karachiensis PLA } \mathrm{A}_{2} \text { in } \\
\text { terms of an increase in pH of an egg yolk } \\
\text { suspension. Neutralized the anticoagulant effect } \\
\text { induced by weak phospholipase A enzymes in } \mathrm{N} \text {. } \\
\text { naja karachiensis venom (40\% inhibition, } \\
\text { coagulation time of } 115 \pm 1.52 \mathrm{~s} \text { ). }\end{array}$ & $\begin{array}{l}\text { Quercetin, scordinines A, B allicin, thiosulfinates, } \\
2 \text { mercapto-L-cysteines, anthocyanins, alliinase, } \\
\text { polysaccharides, sativin I, sativin II, glycosides of } \\
\text { kaempferol }\end{array}$ & $\begin{array}{l}{[123,} \\
125 \\
126]\end{array}$ \\
\hline $\begin{array}{l}\text { Asystasia spp } \\
\text { (A. gangetica } \\
\text { L) }\end{array}$ & Leaves & Methanol & $\begin{array}{l}1000 \mathrm{mg} / \mathrm{kg} \text { provided } 80 \% \text { protection against } \mathrm{N} \text {. } \\
\text { melanoleuca venom }\left(\mathrm{PLA} \mathrm{A}_{2}\right)\end{array}$ & Flavonoids, saponins and tannins & {$[128]$} \\
\hline $\begin{array}{l}\text { Aristolochia } \\
\operatorname{spp}(\text { A. indica, } \\
\text { A. } \\
\text { odoratissima) }\end{array}$ & Leaves & $\begin{array}{l}\text { Methanol, } \\
\text { Ethanol, } \\
\text { Water, } \\
\text { pentane }\end{array}$ & $\begin{array}{l}\mathrm{PLA}_{2} \text { and hyaluronidase enzymes from N. naja } \\
\text { and } V \text {. russelli venoms inhibited. Strong } \\
\text { gelatinolytic, collagenase, peroxidase, and } \\
\text { nuclease activities, L-amino acid oxidase and } \\
\text { protease inhibitory potencies. Protected mice } \\
\text { against lethal effects of Bothrops atrox venom at } \\
\text { higher doses of } 8 \text { and } 16 \mathrm{mg} / \mathrm{kg}\end{array}$ & Aristolochic acid I, lignan (-)-cubebin & $\begin{array}{l}{[129-} \\
131]\end{array}$ \\
\hline Basella alba $\mathrm{L}$. & Fruit & Methanol & $\begin{array}{l}\text { Radical scavenging activity against 1,1-diphenyl 2- } \\
\text { picrylhydroxyl (DHPP) experimented in mice. }\end{array}$ & $\begin{array}{l}\text { Flavonoids, phenolics, betacyanins, Lupeol, } \beta \\
\text { sitosterol }\end{array}$ & $\begin{array}{l}{[132-} \\
134]\end{array}$ \\
\hline $\begin{array}{l}\text { Capparis } \\
\text { tomentosa } \\
\text { Lam. }\end{array}$ & Root & $\begin{array}{l}\text { Water, } \\
\text { petroleum } \\
\text { ether }\end{array}$ & $\begin{array}{l}\text { The antioxidant activity by DPPH was } 35.50 \pm \\
0.02 \% \text {, by phosphomolybdate assay was } 41.22 \pm \\
0.17 \mathrm{mg} / \mathrm{kg} \text { ascorbic acid equivalent, and the }\end{array}$ & $\begin{array}{l}\text { N-benzoylphenylalanylaninol acetate, 24- } \\
\text { ethylcholestan-5-en-3-ol, L-stachydrine, 3- } \\
\text { hydroxy-3-methyl-4-methoxyoxindole }\end{array}$ & $\begin{array}{l}{[135,} \\
136]\end{array}$ \\
\hline
\end{tabular}

$0.17 \mathrm{mg} / \mathrm{kg}$ ascorbic acid equivalent, and the reducing power increased with increase in concentration up to a maximum at $800 \mu \mathrm{g} / \mathrm{ml}$ in alloxanized male mice (aqueous extracts).

$\begin{array}{llll}\text { Carica } & \text { Leaves } & \text { Water, } & \text { Hepatoprotective against carbon tetrachloride } \\ \text { papaya L. } & & \text { ethanol } & \text { induced hepatotoxicity in mice. }\end{array}$

Carissa spp Leaves Methanol Acetylcholinesterase, PLA, hyaluronidase, (C. spinarum phosphomonoesterase, phosphodiesterase,5L.) nucleotidase enzymes from Bungarus caeruleus and $V$. russelli venoms inhibited by $100 \mu \mathrm{g} / \mathrm{ml}$ of the extract.

$\begin{array}{lll}\text { Cassia } & \text { Leaves, Ethanol } & \begin{array}{l}\text { Stimulated angiogenesis, inhibited epidermal } \\ \text { occidentalis L. } \\ \text { hoots }\end{array} \\ & \text { by Bootrops moojeni venom. }\end{array}$

Citrus spp. Root, ripe Methanol Neutralized the anticoagulant effect induced by (C. limon L. fruits weak PLA $\mathrm{A}_{2}$ enzymes in N. naja karachiensis Burm. F) venom (64\% inhibition, coagulation time of 109 $\pm 1.00 \mathrm{~s}$ ). In vitro inhibitory ability against the lethal effect of Lachesis muta venom with effective dose $50 \%$ of $710 \mu \mathrm{g}$ extract per mouse

Saponins, cardiac glycosides, alkaloids, phenolic [137acids, chlorogenic acid, flavonoids and 140] coumarin compounds

Steroids, flavonoids, tannins, saponins, alkaloids, [141, ursolic acid

Anthraquinones [143,

$d$-x-pinene camphene, $d$-limonene, linalool, $\quad$ [126, ichangin 4- $\beta$-glucopyranoside, nomilinic acid, 145, 4- $\beta$-glucopyranoside 
Table 3 Antivenin activities of some plants used for snakebite treatment in Uganda as per global reports (Continued)

\begin{tabular}{|c|c|c|c|c|c|}
\hline Plant & Part used & $\begin{array}{l}\text { Solvent } \\
\text { used }\end{array}$ & Antivenin activity (comments) & Active chemical constituents & Authors \\
\hline $\begin{array}{l}\text { Cleome spp } \\
\text { (C. viscosa) }\end{array}$ & Bulb & $\begin{array}{l}\text { Methanol, } \\
\text { ethyl } \\
\text { acetate }\end{array}$ & $\begin{array}{l}\text { Significant anti-inflammatory activity against cara- } \\
\text { geenin-, histamine-, dextran-induced rat paw } \\
\text { edema compared to Diclofenac sodium ( } 20 \text { mg/ } \\
\text { kg) standard }\end{array}$ & $\begin{array}{l}\text { Flavonoid glycosides, querection 3-0-(2"-acetyl)- } \\
\text { glucoside, phenolics }\end{array}$ & $\begin{array}{l}{[147,} \\
148]\end{array}$ \\
\hline $\begin{array}{l}\text { Crinum spp } \\
\text { (C. jagus) }\end{array}$ & Bulb & Methanol & $\begin{array}{l}\text { Extract of } 1000 \mathrm{mg} / \mathrm{kg} \text { protected } 50 \% \text { of mice; } \\
\text { injection of a pre-incubated mixture of the same } \\
\text { extract dose and venom gave } 100 \% \text { protection } \\
\text { against E. ocellatus venom ( } 10 \mathrm{mg} / \mathrm{kg} \text { ). Adminis- } \\
\text { tration of extract at } 250 \mathrm{mg} / \mathrm{kg}, 30 \mathrm{~min} \text { before } \\
\text { the injection of E. ocellatus venom (10 mg/kg) } \\
\text { prolonged ( } p<0.05 \text { ) death time of poisoned } \\
\text { mice. Extract of } 500 \mathrm{mg} / \mathrm{kg} \text { provided } 50 \% \text { protec- } \\
\text { tion against Betans venom ( } 9.5 \mathrm{mg} / \mathrm{kg} \text { ) while pre- } \\
\text { incubation of a mixture of the same dose of } \\
\text { venom and extract prior to injection provided } \\
33.3 \% \text { protection. Plasma creatine kinase concen- } \\
\text { trations in poisoned mice reduced with injection } \\
1000 \mathrm{mg} / \mathrm{kg} \text { of extract pre-incubated with } 5 \mathrm{mg} / \\
\mathrm{kg} \text { of } E \text {. ocellatus or } 7 \text { mg } / \mathrm{kg} B \text {. arietans venoms. } \\
\text { The extract blocked hemorrhagic activity of a } \\
\text { standard hemorrhagic dose }(2.8 \mathrm{mg} / \mathrm{ml} \text { ) of E. ocel- } \\
\text { latus venom at } 1.7,3.3 \text {, and } 6.7 \mathrm{mg} / \mathrm{ml} \text {. }\end{array}$ & $\begin{array}{l}\text { Phenolic compounds, tannins, alkaloids, cardiac } \\
\text { glycosides }\end{array}$ & $\begin{array}{l}{[148,} \\
149]\end{array}$ \\
\hline
\end{tabular}

Indigofera Leaves Methanol, Extracts reduced bleeding and clotting times of

spp.

(l. capitata

Kotschy, I.

conferta

Gillett)

ethanol, N. nigricollis envenomed rats. Ethanol and water aqueous extracts of $I$. capitata were more effective at dose of $300 \mathrm{mg} / \mathrm{kg}$ with lowest clotting time of $174 \pm 3.67 \mathrm{~s}$ and $1000 \mathrm{mg} / \mathrm{kg}$ with lowest bleeding time of $228 \pm 3.00 \mathrm{~s}$. I.

\begin{tabular}{|c|c|c|}
\hline $\begin{array}{l}\text { (I. pulchra } \\
\text { Willd.) }\end{array}$ & Methanol & \\
\hline $\begin{array}{l}\text { Jatropa } \\
\text { carcus L. }\end{array}$ & Leaf latex & Methanol \\
\hline $\begin{array}{l}\text { Vernonia } \\
\text { cinerea }(\mathrm{L}) \\
\text { Less. }\end{array}$ & $\begin{array}{l}\text { Whole } \\
\text { plant }\end{array}$ & Methanol \\
\hline $\begin{array}{l}\text { Sansevieria } \\
\text { spp } \\
\text { (S. liberica } \\
\text { ger. and labr) }\end{array}$ & $\begin{array}{l}\text { Rhizome, } \\
\text { root }\end{array}$ & Methanol \\
\hline
\end{tabular}

Albizia spp (A. Root/bark Water lebbeck $\mathrm{L}$. (Benth) bark)

$\begin{array}{lll}\begin{array}{l}\text { Euphorbia } \\ \text { species (E. }\end{array} & \text { Whole } & \text { Methanol } \\ \text { hirta) } & & \\ \text { Bidens pilosa } & \text { Leaves, } & \text { water, } \\ \text { L. } & \text { whole } & \text { hexane }\end{array}$
conferta at a dose of $1000 \mathrm{mg} / \mathrm{kg}$ had the lowest clotting time of $173 \pm 5.61 \mathrm{~s}$ (ethanol extract) and $234 \pm 7.64 \mathrm{~s}$ for aqueous extract). Edema forming activity was inhibited by ethanol and aqueous extracts, effective at higher doses of $300 \mathrm{mg} / \mathrm{kg}$ (ethanol extract) and $1000 \mathrm{mg} / \mathrm{kg}$ (aqueous extract) with the lowest edema forming activity of $108.80 \pm 1.90$ and $102.00 \pm 1.90(\% \mathrm{~mm})$ respectively by I. capitata and at dose of $250 \mathrm{mg} /$ $\mathrm{kg}, 500 \mathrm{mg} / \mathrm{kg}$, and $1000 \mathrm{mg} / \mathrm{kg}$ of aqueous extract with the lowest edema forming activities of $100.8 \pm 1.89,100.20 \pm 1.90$ and $100.60 \pm 1.90$ (\%mm) by I. conferta

Extract inhibited anticoagulant, hemolytic and $\mathrm{PLA}_{2}$ activities of $N$. nigricollis venom

Inhibits hemolytic activity of $\mathrm{PLA} 2$ from $N$. naja venom

Antioxidant activity by DPPH free radical scavenging assay. Ethyl acetate fraction exhibited $63.3 \%$ DPPH radical scavenging activity at 100 $\mu \mathrm{g} / \mathrm{ml}$.

$\mathrm{LD}_{50}$ of $353.5 \mathrm{ug} / \mathrm{kg}$. The extract, n-hexane, ethyl acetate, and butanol fractions significantly protected mice from $N$. naja nigricollis venominduced mortality

1000 mg/kg, N. kauothia venom, provided 50\% protection from $N$. naja karachiensis $\mathrm{PLA}_{2}$ in terms of an increase in $\mathrm{pH}$ of an egg yolk suspension

$\mathrm{LD}_{50}$ not specified, against $N$. naja) venom

Effective against Dendroaspis jamesoni and Echis ocellatus venom
Flavonoids, phenolic compounds, steroids, triterpenes, anthraquinone, alkaloids
Tannins, flavonoids, saponins, and steroids

Terpenoids, alkaloids, phenolics, flavonoids, saponins

Phenolics, flavonoids

Terpenoids, flavonoids, saponins

Carbohydrates, proteins, alkaloids, flavonoids, tannins, echinocystic acid, amino acids

Quercetin-3-O-alpha-rhamnoside, terpenoids, [155, alkaloids, steroids, tannins, flavonoids, phenolic 156] compounds

Linalool, Cadinene, -Caryophyllene, - $\quad$ [157, Cubebene, Cedrene, Humulene, Selina-3,7(11)- 158] 
Table 3 Antivenin activities of some plants used for snakebite treatment in Uganda as per global reports (Continued)

\begin{tabular}{|c|c|c|c|c|c|}
\hline Plant & Part used & $\begin{array}{l}\text { Solvent } \\
\text { used }\end{array}$ & Antivenin activity (comments) & Active chemical constituents & Authors \\
\hline & part & & & $\begin{array}{l}\text { diene, Thujopsene, (-)-Globulol, Elixene, 2- } \\
\text { Hexen-1-ol, 2-Hexenal }\end{array}$ & \\
\hline $\begin{array}{l}\text { Hoslundia } \\
\text { opposita Vahl }\end{array}$ & $\begin{array}{l}\text { Root, } \\
\text { leaves }\end{array}$ & $\begin{array}{l}\text { Methanol, } \\
\text { Water }\end{array}$ & $\begin{array}{l}\text { DPPH radical scavenging activity of } 32.3 \pm 1.9 \mu \mathrm{\mu g} / \\
\mathrm{ml} \text { compared to standard L-ascorbic acid with the } \\
\text { activity of } 21.1 \pm 1.1 \mu \mathrm{g} / \mathrm{ml} \text {. }\end{array}$ & -Cadinol Ethyl linolenate, Palmitic acid & $\begin{array}{l}{[158,} \\
159]\end{array}$ \\
\hline $\begin{array}{l}\text { Maytensus } \\
\text { senegalensis }\end{array}$ & Root & $\begin{array}{l}\text { Methanol, } \\
\text { chloroform }\end{array}$ & $\begin{array}{l}\text { Anti-inflammatory activity inhibited ear edema } \\
\text { induced by croton oil in mice }\end{array}$ & Maytenoic acid, lupenone, $\beta$-amyrin & {$[160]$} \\
\hline $\begin{array}{l}\text { Securinega } \\
\text { virosa }\end{array}$ & Leaves & $\begin{array}{l}\text { Hexane, } \\
\text { ethyl } \\
\text { acetate, } \\
\text { methanol }\end{array}$ & $\begin{array}{l}\text { N-hexane extract provided protection against } \\
\text { lethal dose of Naja nigricollis venom (significant } \\
\text { at } 20 \mathrm{mg} / \mathrm{kg}, p<0.05 \text { ) }\end{array}$ & $\begin{array}{l}\text { Alkaloids, phenols, saponins and triterpenes/ } \\
\text { steroids }\end{array}$ & $\begin{array}{l}{[161,} \\
162]\end{array}$ \\
\hline $\begin{array}{l}\text { Solanum } \\
\text { incanum L. }\end{array}$ & Root & Water & $\begin{array}{l}\text { Inhibited the response to acetylcholine in a } \\
\text { concentration-dependent manner like atropine. The } \\
\text { extract inhibited charcoal travel in mice intestine by } \\
36.28,51.45,52.93 \text {, and } 38.53 \% \text { in doses of 50, 100, } \\
200 \text {, and } 400 \mathrm{mg} / \mathrm{kg} \text { body weight respectively }\end{array}$ & $\begin{array}{l}\text { Quercetin, Isoquercitrin, Kaempferol, } \beta \text { - } \\
\text { Sitosterol, Luteolin 7-O-b-D-glucopyranoside, } \\
\text { sodium, potassium, chromium, vitamins B and } \\
\text { C }\end{array}$ & $\begin{array}{l}{[162-} \\
165]\end{array}$ \\
\hline
\end{tabular}

methanolic extracts of Jatropa curcas L. were more effective than the aqueous and chloroform fractions in inhibiting phospholipase $\mathrm{A}_{2}$ activity. The authors attributed this to the possible presence of divalent ions (Calcium (II), Strontium (II), and Barium (II) ions) or quercetin-like compounds which are reported to augment the activity of phospholipase $\mathrm{A}_{2}$ through induction of conformational changes in its substrate-binding sites $[167,168]$. Table 3 summarizes some of the solvents employed by studies done on antivenom activity of some plants reported in this survey. It is worth noting that methanol appears to be the solvent of choice probably because of its ability to dissolve both polar and nonpolar compounds $[169,170]$.

Testing for the efficacy of plants as antivenins has been perfected using mice as the test specimens. Experimentally, the extracts are tested against the lethal dose of the venom that causes death of $50 \%$ of the subjects $\left(\mathrm{LD}_{50}\right)$. Tests are done either in vivo or in vitro on specific toxic activities of venoms. So far, the inhibitory activity of most extracts has been tested against phospholipase $A_{2}$, one of the toxic constituents of snake venoms [111].

\section{Conclusions and recommendations}

Uganda has over 125 districts hence less than $1 \%$ of the country have been surveyed for antivenin plants. The inventory of plants utilized by Ugandan communities present considerable potential for the treatment of snake envenomation. The present review therefore opens the lead for isolation and elucidation of the chemical structures of the antivenom compounds from the claimed plants that could be harnessed in combined therapy with commercial antiserum. There is a need for concerted efforts by scholars, traditional healers, local authorities, and the state to address the ongoing African snakebite crisis and meet World Health Organizations' great interest in documenting the various medicinal plants utilized by different tribes worldwide.

\section{Supplementary information}

Supplementary information accompanies this paper at https://doi.org/10. 1186/s41182-019-0187-0.

Additional file 1. Family, local name, botanical name, growth habit, conservation status, part used, method of preparation and route of administration of antivenin plants used in different districts of Uganda.

\section{Abbreviations \\ DPPH: 1,1- diphenyl 2-picrylhydroxyl; DPPH-1,1: Diphenyl 2-picrylhydroxyl; $L_{50}$ : Median lethal dose; N. naja: Naja naja; PLA : Phospholipase A; spp: Species; V. russelli: Viper russelli}

\section{Acknowledgements}

$\mathrm{TO}, \mathrm{KMK}$, and $\mathrm{OB}$ are grateful to the World Bank and the Inter-University Council of East Africa (IUCEA) for the scholarship awarded to them through the Africa Centre of Excellence II in Phytochemicals, Textiles and Renewable Energy (ACE II PTRE) at Moi University, Kenya, that prompted this ethnomedical communication. The authors commend preceding authors for their fruitful quest for knowledge on medicinal plants utilized by rural communities of Uganda.

\section{Authors' contributions}

$\mathrm{TO}, \mathrm{SK}$, and $\mathrm{OB}$ designed the study. $\mathrm{AO}, \mathrm{TO}, \mathrm{SS}$, and KMK performed the literature search. TO, AO, TO, KMK, and OB analyzed the collected data. TO, SK, TO, SS, and OB verified the plant names in botanical databases, Lusoga, Lango, Luganda, and Acholi, respectively. TO, SK, AO, TO, and OB wrote the first draft of the manuscript. All authors revised and approved the final manuscript.

\section{Funding}

This research received no external funding.

\section{Availability of data and materials}

This is a review article and no raw experimental data was collected. All data generated or analyzed during this study are included in this published article.

Ethics approval and consent to participate Not applicable 


\section{Consent for publication}

Not applicable

\section{Competing interests}

The authors declare that they have no competing interests.

\section{Author details}

'Department of Chemistry and Biochemistry, School of Biological and Physical Sciences, Moi University, Uasin Gishu County, Kesses, P.O.Box 3900-30100, Eldoret, Kenya. ${ }^{2}$ Department of Quality Control and Quality Assurance, Product Development Directory, AgroWays Uganda Limited, Plot 34-60, Kyabazinga Way, P.O. Box 1924, Jinja, Uganda. ${ }^{3}$ Department of Chemistry, Faculty of Science, Kyambogo University, P.O. Box 1, Kampala, Uganda. ${ }^{4}$ Department of Quality Control and Quality Assurance, Product Development Directory, Kakira Sugar Limited, P.O. Box 121, Jinja, Uganda. ${ }^{5}$ Department of Paediatric and Child Health, Faculty of Medicine, Gulu University, P.O.Box 166, Gulu, Uganda. ${ }^{6}$ Department of Biochemistry, Faculty of Health Sciences, Lira University, P.O. Box 1035, Lira, Uganda. ${ }^{7}$ Directorate of Government Analytical Laboratory, Ministry of Internal Affairs, P.O. Box 2174, Kampala, Uganda. ${ }^{8}$ Department of Mechanical Engineering, School of Engineering, Moi University, Uasin Gishu County, Kesses, P.O. Box 3900-30100, Eldoret, Kenya. ${ }^{9}$ Department of Manufacturing, Industrial and Textile Engineering, School of Engineering, Moi University, Uasin Gishu County, Kesses, P.O. Box 3900-30100, Eldoret, Kenya.

\section{Received: 21 October 2019 Accepted: 26 November 2019} Published online: 11 February 2020

\section{References}

1. WHO. Guidelines for the production, control and regulation of snake antivenom immunoglobulins. Geneva: World Health Organization; 2010. https://www.who.int/biologicals/expert_committee/Antivenom_WHO_ Guidelines_DJ. Accessed 29 Sept 2019.

2. Gutiérrez JM, Warrell DA, Williams DJ, Jensen S, Brown N, Calvete JJ. Global snakebite initiative. The need for full integration of snakebite envenoming within a global strategy to combat the neglected tropical diseases: the way forward. PLoS Negl Trop Dis. 2013;7:2162.

3. Chippaux JP. Snake-bites: appraisal of the global situation. Bull World Health Organ. 1998;76:515-24

4. Warrell DA, Arnett C. The importance of bites by the saw-scaled or carpet viper (Echis carinatus): epidemiological studies in Nigeria and a review of the world literature. Acta Trop. 1976;33:307-41.

5. Theakston RDG, Warrell DA, Griffiths E. Report of a WHO workshop on the standardization and control of antivenoms. Toxicon. 2003;41:541-57.

6. Wangoda R, Watmon B, Kisige M. Snakebite management: experiences from Gulu Regional Hospital. Uganda. East Cent Afr J Surg. 2004;9:1-5.

7. Snow RW, Bronzan R, Roques T, Nyamawi C, Murphy S, Marsh K. The prevalence and morbidity of snake bite and treatment seeking behavior among a rural Kenyan population. Annals Trop Med Parasitol. 1994;88:665-71.

8. Fact sheet snakebite incidents, response \& antivenom supply (Uganda), 2018. https://aidstream.org/files/documents/Fact-Sheet-Uganda-ResearchSnakebite-20190128010145.pdf.

9. Gutierrez JM, Rojas E, Quesada L, Leon G, Nunez J, Laing GD, et al. PanAfrican polyspecific antivenom produced by caprylic acid purification of horse IgG: an alternative to the antivenom crisis in Africa. Trans R Soc Trop Med Hyg. 2005;99:468-75.

10. Daily monitor. Using nature to get rid of snakes and their venom. 2015. https://www.monitor.co.ug/Magazines/HealthLiving/Using-nature-to-get-ridof-snakes-and-their-venom/689846-2852038-78tprn/index.html. Accessed 23 July 2019.

11. Warrel DA. Snake bite. Seminar. Lancet. 2010;375:77-88.

12. Zolfagharian H, Dounighi NM. Study on development of Vipera lebetina snake anti-venom in chicken egg yolk for passive immunization. Hum Vaccin Immunother. 2015;11:2734-9.

13. Kasturiratne A, Wickremasinghe AR, de Silva N, Gunawardena NK, Pathmeswaran A, Premaratna R, et al. The global burden of snakebite: a literature analysis and modelling based on regional estimates of envenoming and deaths. PLoS Med. 2008:5:11.

14. Bauchot R. Snakes: A Natural History. New York: Sterling Publishing Co. Inc 1994.
15. Dreisbach $\mathrm{RH}$, Rebertson WO. Reptiles: snakes. In: A handbook of poisoning. 12th ed: Los Altos: a LANGE Medical Book; 1987.

16. Musah Y, Ameade EPK, Attuquayefio DK, Holbech LH. Epidemiology, ecology and human perceptions of snakebites in a savanna community of northern Ghana. PLoS Neg Trop Dis. 2019;13:8.

17. Owuor BO, Kisangau DP. Kenyan medicinal plants used as antivenin: a comparison of plant usage. Ethnobiol Ethnomed. 2006;2:7.

18. New Vision. Sleeping with snakes at Musambwa. 2018. https://www. newvision.co.ug/new_vision/news/1197460/sleeping-snakes-musambwa.

19. Gold BS, Barish RA, Dart RC. North American snake envenomation: diagnosis, treatment, and management. Emerg Med Clin N Am. 2014:22:423-43.

20. Figueroa A, McKelvy AD, Grismer $L L$, Bell CD, Lailvaux SP. A species-level phylogeny of extant snakes with description of a new colubrid subfamily and genus. PLOS ONE. 2016;11:9.

21. New Vison. Many snake victims buried alive. 2013. https://www.newvision. co.ug/new_vision/news/1314577/snakebite-victims-buried-alive Accessed 23 July 2019.

22. Daily Monitor. No drug to treat snakebite victims. 2019. https://www. monitor.co.ug/News/National/No-drugs-treat-snakebite-victims/688334-496 0770-pq9rnlz/index.html.

23. Guimaraes CLS, Moreira-Dill LS, Fernandes RS, Costa TR, Hage-Melim LIS Calderon, et al. Biodiversity as a source of bioactive compounds against snakebites. Current Med Chem. 2014;21:2952-79.

24. Goswani PK, Samant M, Srivastava R. Snake venom, anti-snake venom \& potential of snake venom. Int J Pharm Pharmaceut Sci. 2014;6:4-7.

25. Kang TS, Georgieva D, Genov N, Murakami MT, Sinha M, Kumar RP, et al. Enzymatic toxins from snake venom: structural characterization and mechanism of catalysis. FEBS J. 2011;278:4544-76.

26. Janardhan B, V. S, Mirajkar KK, More SS. In vitro screening and evaluation o Janardhan B, Shrikanth VM, Mirajkar KK, More SS. In vitro screening and evaluation of antivenom phytochemicals from Azima tetracantha Lam. leaves against Bungarus caeruleus and Vipera russelli. J Venom Anim Toxins Incl Trop Dis. 2014;20:12.

27. Devi CM, Bai MV, Lal AV, Umashankar PR, Krishnan LK. An improved method for isolation of anti-viper venom antibodies from chicken egg yolk. J Biochem Biophys Method. 2002;51:129-38.

28. Theakston RDG, Warrell DA. Crisis in snake Antivenom supply for Africa. Lancet. 2000;356:2104.

29. Harrison RA, Hasson SS, Harmsen M, Laing GD, Conrath K, Theakston RD. Neutralisation of venom-induced haemorrhage by lgG from camels and llamas immunised with viper venom and also by endogenous, non-lgG components in camelid sera. Toxicon. 2006;47:364-8.

30. Thallay BS, Carroll SB. Rattle snake and scorpion antivenoms from the egg yolks of immunized hens. Biotech (NY). 1990:8:934-8.

31. Asuzu IU, Harvey AL. The antisnake venom activities of Parkia biglobosa (Mimosaceae) stem bark extract. Toxicon. 2003:42:763-8.

32. Ahmed A, Rajendaran K, Jaiswal D, Singh HP, Mishra A, Chandra D, et al. Anti-snake venom activity of different extracts of Pouzolzia indica against Russel viper venom. Int J Chem Tech Res. 2010;2:744-51.

33. Gomes JAS, Félix-Silva J, Fernandes JM, Amaral JG, Lopes NP, Tabosa do Egito ES, et al. Aqueous leaf extract of Jatropha mollissima (Pohl) bail decreases local effects induced by Bothropic venom. BioMed Res Int. 2016. https://doi.org/10.1155/2016/6101742.

34. Anywar G, Charlotte IEA, Klooster V, Byamukama R, Willcox M, Nalumansi PA, et al. Medicinal plants used in the treatment and prevention of malaria in Cegere sub-county. Northern Uganda. Ethnobot Res Appl. 2016;14:505-16.

35. Namukobe J, Kasenene JM, Kiremire BT, Byamukama R, Kamatenesi-Mugisha $\mathrm{M}$, Krief $\mathrm{S}$, et al. Traditional plants used for medicinal purposes by local communities around the northern sector of Kibale National Park. Uganda. J Ethnopharmacol. 2011;136:236-45.

36. Stangeland T, Alele PE, Katuura E, Lye KA. Plants used to treat malaria in Nyakayojo sub-county. Western Uganda. J Ethnopharmacol. 2011;137:154-66.

37. Adia MM, Anywar G, Byamukama R, Kamatenesi-Mugisha M, Sekagya Y, Kakudidi EK, et al. Medicinal plants used in malaria treatment by Prometra herbalists in Uganda. J Ethnopharmacol. 2014;155:580-8.

38. Okello J, Ssegawa P. Medicinal plants used by communities of Ngai Subcounty, Apac district. Northern Uganda. Afr J Ecol. 2007:45:76-83.

39. Hamill FA, Apio S, Mubiru NK, Mosango M, Bukenya-Ziraba R, Maganyi OW, et al. Traditional herbal drugs of Southern Uganda. J Ethnopharmacol. 2000; 70:281-300. 
40. Okullo JBL, Omujal F, Bigirimana C, Isubikalu P, Malinga M, Bizuru E, et al. Ethno-medicinal uses of selected indigenous fruit trees from the Lake Victoria basin districts in Uganda. J Med Plants Stud. 2014;2:78-88.

41. Oryema C, Bukenya Ziraba R, Omagor N, Opio A. Medicinal plants of Erute county, Lira district, Uganda with particular reference to their conservation. Afr J Ecol. 2010;48:285-98.

42. Tabuti JRS, Lye LA, Dhillion SS. Traditional herbal drugs of Bulamogi, Uganda: plants, use and administration. J Ethnopharmacol. 2003:88:19-44.

43. Lamorde M, Tabuti JRS, Obua C, Kukunda-Byobona C, Lanyero H, ByakikaKibwika $P$, et al. Medicinal plants used by traditional medicine practitioners for the treatment of HIV/AIDS and related conditions in Uganda. J Ethnopharmacol. 2008. https://doi.org/10.1016/j.jep.2010.04.004.

44. Opio DR, Andama E, Kureh GT. Ethnobotanical survey of antimalarial plants in areas of: Abukamola, Angeta, Oculokori and Omarari of Alebtong district in Northern Uganda. Eur J Med Plant. 2017;21:1-14.

45. Katuura E, Waako P, Ogwal-Okeng J, Bukenya-Ziraba R. Traditional treatment of malaria in Mbarara district. Western Uganda. Afr J Ecol. 2007;45:48-51.

46. Kamatenesi MM, Acipa A, Oryem-Origa H. Medicinal plants of Otwal and Ngai Sub counties in Oyam district. Northern Uganda. J Ethnobiol Ethnomed. 2011;7:7.

47. Nambejja C, Tugume P, Nyakoojo C, Kamatenesi-Mugisha M. Medicinal plant species used in the treatment of skin diseases in Katabi subcounty, Wakiso district. Uganda. Ethnobot Res Appl. 2019;18:1-17.

48. Ssegawa P, Kasenene JM. Plants for malaria treatment in Southern Uganda: Traditional use, preference and ecological viability. J Ethnobiol. 2007;27:110-31.

49. Tugume P, Kakudidi EK, Buyinza M, Namaalwa J, Kamatenesi M, Mucunguzi $P$, et al. Ethnobotanical survey of medicinal plant species used by communities around Mabira Central Forest Reserve. Uganda. J Ethnobio Ethnomed. 2016;12:5.

50. Kodi P, Mwangi ME, Kiplagat CP, Karuiki TS. Ethnobotanical survey of antimalarial medicinal plants used in Butebo county. Eastern Uganda. Eur Med Plant. 2017;21:1-22.

51. Oryem-Origa H, Kakudidi EK, Katende AB, Bukenya-Ziraba R. Utilization of medicinal plants in Bundibugyo district, Uganda. In: Kinyua A, KofiTsekpo WM, Dangana LB, editors. Conservation and utilization of indigenous medicinal plants and wild relatives of food crops. Nairobi: UNESCO; 1997. p. 75-80.

52. Tabuti JRS, Kukunda CB, Waako WJ. Medicinal plants used by traditional medicine practitioners in the treatment of tuberculosis and related ailments in Uganda. J Ethnopharmacol. 2010;127:130-6.

53. Tabuti JRS, Dhillion SS, Lye KA. Traditional medicine in Bulamogi County, Uganda. Its practitioners, users \& viability. J Ethnopharmacol. 2003;85:1 19-29.

54. Kakudidi EK, Bukenya-Ziraba R, Kasenene JM. The medical plants in and around Kibale National Park in western Uganda. Lidia. 2000;4:109-24.

55. Kibuuka MS, Anywar G. Medicinal plant species used in the management of hernia by traditional medicine practitioners in central Uganda. Ethnobot Res Appl. 2015;14:289-98.

56. Katuura E, Kalabika E, Lubega A. Uterotonic potential of selected plants used by Ugandan local communities in the treatment of malaria. Eur J Med Plant. 2018;24:1-12.

57. Tabuti JRS, Kukunda CB, Kaweesi D, Kasilo OMJ. Herbal medicine used in the districts of Nakapiripirit, Pallisa. Kanungu and Mukono in Uganda. J Ethnobiol Ethnomed. 2012;8:35

58. Nalumansi P, Kamatenesi-Mugisha M, Anywar G. Medicinal plants used in paediatric health care in Namungalwe sub county, Iganga district. Uganda. Nova J Med Biol Sci. 2014;2:1-14.

59. Lacroix D, Prado S, Kamoga D, Kasenene J, Namukobe J, Krief S, et al. Antiplasmodial and cytotoxic activities of medicinal plants traditionally used in the village of Kiohima. Uganda. J Ethnopharmacol. 2011;133:850-5.

60. Anywar G, Oryem-Origa H, Kamatenesi MM. Wild Plants used as nutraceuticals from Nebbi district. Uganda. Eur J Med Plant. 2014;4:641-60.

61. Omara T, Karungi S, Ssebulime S, Kiplagat KM, Bongomin O, Ogwang R, et al. Artisanal and small-scale gold mining in Syanyonja, Busia gold district, South Eastern Uganda: Impacts on the mining population and the environment. Asian J Geol Res. 2019;2(4):1-13.

62. Omara T, Nassazi W, Omute T, Awath A, Laker F, Kalukusu R, et al. Aflatoxins in Uganda: An encyclopedic review of the etiology, epidemiology, detection, quantification, exposure assessment, reduction and control. Int J Microbiol. 2020; (in press) https://doi.org/10.1155/2020/4723612.

63. Bukenya-Ziraba R, Doenges P, Duez P, Lejoly J, Ogwal-Okeng J. Medicinal plants sub-sector review: pharmacopoeia promoting programme preparatory study, draft of final report to Ministry of Health. Archive, Ministry of Health: Uganda; 1996.

64. Omara T. Antibacterial activity of papain hydrolysates of isoelectricallyisolated casein and thermoprecipitated alpha-lactalbumin from bovine and caprine milk on diarrheagenic bacteria. J Adv Med Life Sci. 2019;7:1-6.

65. Scopus. https://www.scopus.com/. Accessed 13 July 2019.

66. Web of Science. http://www.webofknowledge.com/. Accessed 20 July 2019.

67. PubMed. https://www.ncbi.nlm.nih.gov/pubmed/. Accessed 16 Sept 2019

68. Science Direct. http://www.sciencedirect.com/. Accessed 7 July 2019.

69. Google Scholar. https://scholar.google.com.br/. Accessed 30 Aug 2019.

70. Scientific Electronic Library Online. http://www.scielo.org/. Accessed 29 July 2019.

71. The Plant List. http://www.theplantlist.org/. Accessed 29 July 2019.

72. International Plant Names Index. https://www.ipni.org/?q=http\%3A\%2F\%2 Fipni.org\%2Furn\%3Alsid\%3Aipni.org\%3Anames\%3A295763-1. Accessed 30 Aug 2019.

73. NCBI taxonomy browser. https://www.ncbi.nlm.nih.gov/taxonomy.

74. Tropicos. http://www.tropicos.org/. Accessed 12 Aug 2019.

75. DW News. The island of men and snakes. 2019. https://www.dw.com/en/ the-island-of-men-and-snakes/av-48360195.

76. Owuor BO, Mulemi BA, Kokwaro JO. Indigenous snake bite remedies of the Luo of western Kenya. J Ethnobiol. 2005;20:129-41.

77. Ruffo CK. A Survey of medicinal plants in Tabora region, Tanzania. In: Traditional Medicinal Plants. Tanzania: Dar es Salaam University Press Ministry of Health; 1991.

78. Wodah D, Asase A. Ethnopharmacological use of plants by Sisala traditional healers in northwest Ghana. Pharm Biol. 2012:50:807-15.

79. Cos P, Hermans N, Van Poel B, De Bruyne T, Apers S, Sindambiwe JB, et al. Complement modulating activity of Rwandan medicinal plants. Phytomed. 2002;9:56-61.

80. Issa TO, Mohamed YS, Yagi S, Ahmed RH, Najeeb TM, Makhawi AM, et al. Ethnobotanical investigation on medicinal plants in Algoz area (South Kordofan). Sudan. J Ethnobiol Ethnomed. 2018;14:31.

81. Yirgu A, Chippaux J. Ethnomedicinal plants used for snakebite treatments in Ethiopia: a comprehensive overview. J Venom Anim Toxins incl Trop Dis. 2019;25:e20190017.

82. Shah A, Sarvat R, Shoaib S, Ayodele AE, Nadeem M, Qureshi TM, et al. An ethnobotanical survey of medicinal plants used for the treatment of snakebite and scorpion sting among the people of Namal valley, Mianwali district, Punjab. Pakistan. Appl Ecol Environ Res. 2018;16:111-43.

83. Hassan-Abdallah A, Merito A, Hassan S, Aboubaker D, Djama M, Asfaw Z, et al. Medicinal plants and their uses by the people in the Region of Randa. Djibouti. J Ethnopharmacol. 2013;148:701-13.

84. Abd E-GM. Traditional medicinal plants of Nigeria: an overview. Agric Biol J N Am. 2016;7:220-47.

85. Ndah NR, Egbe AE, Bechem EET, Asaha S, Yengo T, Chia EL, et al. Ethnobotanical study of commonly used medicinal plants of the Takamanda Rainforest South West. Cameroon. Afr J Plant Sci. 2013;7:21-34

86. Upasani SV, Beldar VG, Tatiya AU, Upasani MS, Surana SJ, Patil DS. Ethnomedicinal plants used for snakebite in India: a brief overview. Integr Med Res. 2017:6:114-30

87. Kumar SJU, Chaitanya KMJ, Semotiuk AJ, Krishna V. Indigenous knowledge of medicinal plants used by ethnic communities of South India. Ethnobot Res Appl. 2019;18:1-112.

88. Kadir FM, Karmoker JR, Alam MD, Jahan SR, Mahbub S, Mia MMK. Ethnopharmacological survey of medicinal plants used by traditional healers and indigenous people in Chittagong hill tracts, Bangladesh, for the treatment of snakebite. Evidence-Based Compl Altern Med. 2015. https://doi. org/10.1155/2015/871675

89. Hasan Md N, Azam NK, Ahmed Md N, Hirashima A. A randomized ethnomedicinal survey of snakebite treatment in southwestern parts of Bangladesh. J Tradit Complement Med. 2016;6:6337-42.

90. Giovannini P, Howes MR. Medicinal plants used to treat snakebite in Central America: review and assessment of scientific evidence. J Ethnopharmacol. 2017;199:240-56.

91. Marles RJ, Farnsworth NR. Antidiabetic plants and their active constituents. Phytomed. 1995;2:137-89.

92. Kadir MF, Sayeed MSB, Shams T, Mia MMK. Ethnobotanical survey of medicinal plants used by Bangladeshi traditional health practitioners in the management of diabetes mellitus. J Ethnopharmacol. 2012;144:605-11. 
93. Macedo JGF, De-Menezes IRA, Santos MO, de Macedo DG, Macedo JF, Almedia BV, et al. Analysis of the variability of therapeutic indications of medicinal species in the Northeast of Brazil: comparative study. EvidenceBased Compl Alternat Med. 2018. https://doi.org/10.1155/2018/6769193.

94. Ministry of trade, industry and cooperatives. Kaliro district economic profile. 2016. http://mtic.go.ug/2016/index.php?/The-Project/kaliro-districteconomic-profile/. Accessed 10 Nov 2019.

95. Lira District. Wetlands. 2019. https://iradistrict.com/wetlands/.

96. Lira District. Forestry. 2019. https://iradistrict.com/forestry/.

97. Wikipedia. Mabira forest. 2019. https://en.wikipedia.org/wiki/Mabira_Forest. Accessed 10 Nov 2019

98. East African Jungle Safaris. Mabira forest. 2019. https:// eastafricanjunglesafaris.com/destinations/uganda/mabira-forest-reserve/.

99. Kokwaro JO. Medicinal plants of East Africa. Nairobi: East Africa Education Publishers; 1994

100. Watt JM, Breyer-Brandwijk MG. The medicinal and poisonous plants of Southern and Eastern Africa. E.\&S. Livingstone Ltd: Edinburgh; 1962.

101. Taylor N. Snake root. In: Encyclopaedia Britannica volume 20. Chicago: William Benton; 1970.

102. Omara T, Musau B, Kagoya S. Frugal utilization of flue-cured virginia Nicotiana tabacum leaf wastes as a vicissitudinous substrate for optimized synthesis of pyridine-3-carboxylic acid. Amer J Hetero Chem. 2018:4:49-54

103. Pereira RLC, Ibrahim T, Lucchetti L, Da Silva AJR, De Moraes VLG. Immunosuppressive and anti-inflammatory effects of methanolic extract and the polyacetylene isolated from Bidens pilosa L. Immunopharmacol. 1999:43:31-7.

104. Asad MHHB, Razi MT, Ubaid M, Durr-e-Sabih, Sajjad A, Mehmood R, et al. Naja naja karachiensis envenomation: biochemical parameters for cardiac, liver, and renal damage along with their neutralization by medicinal plants. BioMed Res Int. 2014; doi: https://doi.org/10.1155/2014/970540

105. Tan PV, Dimo T, Dongo E. Effects of methanol, cyclohexane and methylene chloride extracts of Bidens pilosa on various gastric ulcer models in rats. J Ethnopharmacol. 2000;73:415-21.

106. Wiart C. Medicinal plants of Southeast Asia. 2nd ed. Prentice Hall: Upper Saddle River; 2002.

107. Dimo T, Azay J, Tan PV, Pellecuer J, Cros G, Bopdlet M, et al. Effects of the aqueous and methylene chloride extracts of Bidens pilosa leaf on fructosehypertensive rats. J Ethnopharmacol. 2001;76:215-21.

108. Bekalo TH, Woodmatas SD, Woldemariam ZA. An ethnobotanical study of medicinal plants used by local people in the lowlands of Konta Special Woreda, southern nations, nationalities and peoples regional state. Ethiopia. J Ethnobiol Ethnomed. 2009;5:26.

109. Devappa RK, Makkar HPS, Becker K. Jatropha toxicity—a review. J Toxicol Environ Health. 2010;13:476-07.

110. Lin J, Chen Y, Xu Y, Yan F, Tang L, Chen F. Cloning and expression of curcin, a ribosome-inactivating protein from the seeds of Jatropha curcas. Acta Bot Sin. 2003;45:858-63.

111. Mors WB. Plants against snake-bites. Rio de Janeiro: Memoirs Institute Oswaldo Cruz; 1991.

112. Borges MH, Soares AM, Rodrigues VM, Oliveira F, Francheschi AM, Rucavado A, et al. Neutralization of proteases from Bothrops snake venoms by the aqueous extract from Casearia sylvestris (Flacourtiaceae). Toxicon. 2001;39:1863-9.

113. Januario AH, Santos SL, Marcussi S, Mazzi MV, Pietro RC, Sato DN, et al. Neoclerodane diterpenoid, a new metalloprotease snake venom inhibitor from Baccharis trimera (Asteraceae): anti-proteolytic and anti-hemorrhagic properties. Chem Biol Interact. 2004;150:243-51.

114. Vale LHF, Mendes MM, Hamaguchi A, Rodrigues VM, Homsi-Brandeburgo MI, Soares AM. Neutralization of pharmacological and toxic activities of Bothrops snake venoms by Schizolobium parahyba (Fabaceae) aqueous extract and its fractions. Basic Clin Pharmacol Toxicol. 2008;103:104-7.

115. Hung Y-C, Sava V, Hong M-Y, Huang G. Inhibitory effects on phospholipase $\mathrm{A} 2$ and antivenin activity of melanin extracted from Thea sinensis Linn. Life Sci. 2004;74:2037-47.

116. Castro O, Gutiérrez JM, Barrios M, Castro I, Romero M, Umaña E. Neutralization of the hemorrhagic effect induced by Bothrops asper (Serpentes: Viperidae) venom with tropical plant extracts. Revista de Biología Trop. 1999;47:605-16.

117. Alam Ml, Gomes A. Adjuvant effects and antiserum action potentiation by a (herbal) compound 2-hydroxy-4-methoxy benzoic acid isolated from the root extract of the Indian medicinal plant "sarsaparilla" (Hemidesmus indicus R. Br.). Toxicon. 1998;36:1423-31.
118. Gomes A, Das R, Sarkhel S, Mishra R, Mukherjee S, Bhattacharya S, et al. Herbs and herbal constituents active against snakebite. Indian J Exp Biol. 2010;48:865-78.

119. Gupta YK, Peshin SS. Snake bite in India: Current scenario of an old problem. J Clin Toxicol. 2014;4:1-9.

120. Leanpolchareanchai J, Pithayanukul P, Bavovada R, Saparpakorn P. Molecular docking studies and anti-enzymatic activities of Thai mango seed kernel extract against snake venoms. Molecules. 2009;14:1404-22.

121. Toyama D, Marangoni S, Diz-Filho E, Oliveira S, Toyam M. Effect of umbelliferone (7-hydroxycoumarin,7-HOC) on the enzymatic, edematogenic and necrotic activities of secretory phospholipase A2 (SPLA2) isolated from Crotalus durissus collilineatus venom. Toxicon. 2009;53:417-26.

122. Chandra V, Jasti J, Kaur P, Srinivasan A, Betzel C, Singh TP. Structural basis of phospholipase A2 inhibition for the synthesis of prostaglandins by the plant alkaloid aristolochic acid from a 1.7å crystal structure. Biochem. 2002;41:10914-9.

123. Girish KS, Kemparaju K. Inhibition of Naja naja venom hyaluronidase by plant-derived bioactive components and polysaccharides. Biochem. 2005;70: 948-52.

124. Soares AM, Ticli FK, Marcussi S, Lourenço MV, Januário AH, Sampaio SV, et al. Medicinal plants with inhibitory properties against snake venoms. Curr Med Chem. 2005;12:2625-41.

125. Asad MHHB, Sabih DE, Chaudhory BA, Ahmad I, Hussain MS, Izhar N, et al. Anti-hemolytic property of local medicinal plant(s) upon Pakistani cobra venom induced hemolysis. J Anim Plant Sci. 2014;24:1701-8.

126. Asad MHHB, Durr-e-Sabih YT, Murtaza G, Hussain MS, Hussain MS, et al. Phospholipases A2: enzymatic assay for snake venom (Naja naja karachiensis) with neutralization their by medicinal plants of Pakistan. Acta Pol Pharma. 2014:71:625-30.

127. Asad MHHB, Razi MT, Durr-e-Sabih N-SQ, Nasim J, Murtaza G, et al. Antivenom potential of Pakistani medicinal plants: inhibition of anticoagulation activity of Naja naja karachiensis toxin. Current Sci. 2013;105:1419-24.

128. Gujral ML, Dhawan SN. The effect of drugs modifying absorption on death caused by cobra venom in rats. Indian J Med Res. 1956;44:625-9.

129. Enenebeaku CK, Umerie SC, Nwankwo MU, Enenebeaku UE. Anti-Snake venom Activities of the leaf extracts of Asystasia gangetica $(L)$ and Newbouldia leavis (p. Beauv). WNOFNS. 2018;16:33-41.

130. Kemparaju K, Girish KS. Snake venom hyaluronidase: a therapeutic target. Cell Biochem Funct. 2006:24:7-12.

131. Gowda TV. Interaction of snake venom phospholipase A2 with plant isolates. In: Kini RM, editor. Venom phospholipase A2 enzymes: structure, function and mechanism. New York.: Wiley; 1997.

132. Usubillaga A, Khouri N, Cedillo-Vaz YE. Anti-snake venom effect of Aristolochia odoratissima L. aqueous extract on mice. Proc. WOCMAP III, Vol. 3: perspectives in natural product chemistry Eds. K.H.C. Başer, G. Franz, S. Cañigueral, F. Demirci, L.E. Craker and Z.E. Gardner. Acta Hort. 2005;677:85-9.

133. Reshmi SK, Aravindhan KM. P Suganya Devi. Antioxidant analysis of betacyanin extracted from Basella alba fruit. Int J Pharm Tech Res. 2012:4:900-13.

134. Saleem M, Alam A, Arifin S, Shah MS, Ahmed B, Sultana S. Lupeol, a triterpene, inhibits early responses of tumour promotion induced by benzyol peroxide in murine skin. Pharmacol Res. 2001;43:127-34.

135. Gupta AK, Tandon N, Sharma M, Saraswathy A, Sunil Kumar SN, Shakila R, et al. Quality standards of Indian medicinal plants. New Delhi: Indian Council of Medical Research; 2008. pp. xvii + 262.

136. Akoto O, Oppong IV, Addae-Mensah I, Waibel R, Achenbach H. Isolation and characterization of dipeptide derivative and phytosterol from Capparis tomentosa Lam. Sci Res Essay. 2008;3:355-8.

137. Wangai LN, Waithera BM, Karau MG, Koimburi NB, Ndura PK, Karanja R, et al. Investigation of the in vitro antioxidant activity, in vivo antidiabetic efficacy and safety of Capparis tomentosa aqueous roots extracts in male alloxanized mice. J Med Plant Stud. 2015:3:42-7.

138. Pandit A, Sachdeva T, Bafna P. Ameliorative effect of leaves of Carica papaya in ethanol and antitubercular drug induced hepatotoxicity. Br J Pharm Res. 2013;3:648-61.

139. Canini A, D'Arcangelo AG, Tagliatesta P. Gas chromatography-mass spectrometry analysis of phenolic compounds from Carica papaya L. leaf. J Food Compos Anal. 2007;20:584-90.

140. Ayoola PB, Adeyeye A. Phytochemical and nutrient evaluation of Carica papaya (pawpaw) leaves. Int J Res Rev Appl Sci. 2010;5:325-8.

141. Sadeque MZ, Begum ZA, Umar BU, Ferdous AH, Sultana S, Uddin MK. Comparative efficacy of dried fruits of Carica papaya Linn. and Vitamin-E on preventing hepatotoxicity in rats. Faridpur Med College J. 2012;7:29-32. 
142. Janardhan B, Shrikanth VM, Mirajkar KK, More SS. In vitro anti-snake venom properties of Carisssa spinarum Linn leaf extracts. J Herbs Spices Med Plant. 2015;21:283-93.

143. Mathuram V, Brahmadhayalaselvam A. Chemical-constituents of carissaspinarum and their antibacterial activity. J Indian Chem Soc. 1998;75:262-4.

144. Delmut MB, Leila MLP, Paula JR, Conceicao EC, Santos AS, Pfrimer IAH. Cassia occidentalis: Effect on skin wound healing in mice induced by Bootrops moojeni venom. J Pharm Technol Drug Res. 2013;2:1-6.

145. Yadava RN, Satnami DK. Chemical constituents from Cassia occidentalis Linn. Indian J Chem. 2011;50B:1112-8.

146. Ugulu I. Traditional ethnobotanical knowledge about medicinal plants used for external therapies in Alasehir. Turkey. Int J Med Aromat Plants. 2011;1: 101-6.

147. Núñez V, Otero R, Barona J, Fonnegra R, Jiménez S, Osorio RG, et al. Inhibition of the toxic effects of Lachesis muta, Crotalus durissus cumanensis and Micrurus mipartitus snake venoms by plant extracts. Pharm Biol. 2004;42:49-54.

148. Parimala B, Boominathan R, Mandal SC. Evaluation of anti-inflammatory activity of Cleome viscosa. Indian J Nat Prod. 2003;19:8-12.

149. Abubakar UD, Wakili FT. Phytochemical screening and elemental analysis of the Crinum jagus bulb. J Chem Soc Nigeria. 2017;42:53-5.

150. Ode OJ, Asuzu IU. The anti-snake venom activities of the methanolic extract of the bulb of Crinum jagus (Amaryllidaceae). Toxicon. 2006;48:331-42.

151. Kadiri S. Comparative, antibacterial, anti-venom and phytochemical studies of Indigofera capitata Kotschy and Indigofera conferta Gillett in albino rats. PhD thesis. Nigeria: Ahmadu Bello University; 2016.

152. Musa AM, Sule MI, Haruna AK, Ilyas M, lliya I, Yaro AH, et al. Preliminary gastrointestinal studies of methanol extract of Indigofera pulchra willd in rodents. Niger J Pharm Sci. 2008;7:86-92.

153. Sonibare MA, Aremu OT, Okorie PN. Antioxidant and antimicrobial activities of solvent fractions of Vernonia cinereal (L.) Less leaf extract. Afri Health Sci. 2016;16:629-39

154. Chiou YL, Shinne R, Wan PH, Long SC. Quercetin modulates activities of Taiwan Naja naja naja PLA2 via its effects on membrane structure and membrane bound mode of PLA2. J Biosci. 2012;37:277-87.

155. Akah AP, Nwagu TS, Oforkansi MN. Evaluation of the anti-snake venom activity of leaf extract of Sansevieria liberica ger.\& labr (Agavaceae.) in mice. Int J Sci. 2019;8:60-8.

156. Byamukama R, Barbara G, Namukobe J, Heydenreich M, Kiremire BT. Bioactive compounds in the stem bark of Albizia coriaria (Welw. ex Oliver). Int J Biol Chem Sci. 2015;9:1013-24

157. Gopi K, Anbarasu K, Renu K, Jayanthi S, Vishwanath BS, Jayaraman G. Quercetin-3-O-rhamnoside from Euphorbia hirta protects against snake venom induced toxicity. Biochim Biophys Acta. 2016;1860:1528-40.

158. Basma AA, Zakaria Z, Latha LY, Sasidharan S. Antioxidant activity and phytochemical screening of the methanol extracts of Euphorbia hirta L. Asian Pac J Trop Med. 2011:4:386-90.

159. Chippaux J-P, Rakotonirina VS, Rakotonirina A, Dzikouk G. Substances médicamenteuses ou végétales antagonistes du venin ou potentialisant le sérum antivenimeux. Bull Soc Pathol Exot. 1997;9:282-5.

160. Ocheng F, Bwanga F, Joloba M, Softrata A, Azeem M, Pütsep K, et al. Essential oils from Ugandan aromatic medicinal plants: chemical composition and growth inhibitory effects on oral pathogens. EvidenceBased Compl Alternat Med. 2015. https://doi.org/10.1155/2015/230832

161. Annan K, Dickson R. Evaluation of wound healing actions of Hoslundia opposita Vahl, Anthocleista nobilis G. Don. and Balanites aegyptiaca L. J Sci Technol. 2008;28:26-35.

162. Sosa S, Morelli CF, Tubaro A, Cairoli P, Speranza G, Manitto P. Antiinflammatory activity of Maytenus senegalensis root extracts and of maytenoic acid. Phytomed. 2007;14:109-14.

163. Paschal ME, Carreetero ME, Sloving KV, Villar A. Simplified screening by TLC of plant drugs. Pharm Biol. 2002:40:139-41.

164. Auta R, Ali I. Nutritional and chemical value of Solanum incanum (bitter garden egg). Int J Trop Med Pub Health. 2011;1:96-107.

165. Lin C, Lu C, Cheng M, Gan K, Won S. The Cytotoxic principles of Solanum incanum. Natural Prod. 1990;53:513-6.

166. Yun-lian L, Wan-yi W, Kuo YH. Non-steroidal constituents from Solanum incanum. Chin Chem Soc. 2000;47:247-51.

167. Assefa A, Urga K, Guta A, Melaku D, Mekonen W, Melesse M, et al. Spasmolytic activity of the aqueous root extract of Solanum incanum Solanaceae. Ethiop J Biol Sci. 2006;5:137-46.
168. Reddi KVNR, Rajesh SS, Narendra K, Jangala S, Reddy PCO, Satya AK, et al. In vitro anti-venom potential of various Jatropha extracts on neutralizing cytotoxic effect induced by phospholipase A2 of crude venom from Indian cobra (Naja naja). Bangladesh J Pharmacol. 2014;9:22-8.

169. Jiang MS, Fletcher JE, Smith LA. Factors influencing the hemolysis of human erythrocytes by cardiotoxins from Naja naja kaouthia and Naja naja atra venoms and a phospholipase A2 with cardiotoxin-like activities from Bungarus fasciatus venom. Toxicon. 1989;27:247-57.

170. Encyclopaedia Britannica. Methanol. https://www.britannica.com/science/ methanol.

\section{Publisher's Note}

Springer Nature remains neutral with regard to jurisdictional claims in published maps and institutional affiliations.
Ready to submit your research? Choose BMC and benefit from:

- fast, convenient online submission

- thorough peer review by experienced researchers in your field

- rapid publication on acceptance

- support for research data, including large and complex data types

- gold Open Access which fosters wider collaboration and increased citations

- maximum visibility for your research: over $100 \mathrm{M}$ website views per year

At BMC, research is always in progress.

Learn more biomedcentral.com/submissions 